\title{
Emerging Powers and Global Governance: Whither the IMF?
}




\title{
WP/15/219
}

\section{IMF Working Paper}

\section{Emerging Powers and Global Governance: Whither the IMF?}

\author{
By Rakesh Mohan and Muneesh Kapur
}

IMF Working Papers describe research in progress by the author(s) and are published to elicit comments and to encourage debate. The views expressed in IMF Working Papers are those of the author(s) and do not necessarily represent the views of the IMF, its Executive Board, or IMF management.
I N T E R N A T I O N A L
$M O N E T A R Y$
F U N D 


\title{
IMF Working Paper
}

Office of the Executive Director

\section{Emerging Powers and Global Governance: Whither the IMF? \\ Prepared by Rakesh Mohan and Muneesh Kapur}

Authorized for distribution by Rakesh Mohan

October 2015

\section{IMF Working Papers describe research in progress by the author(s) and are published to elicit comments and to encourage debate. The views expressed in IMF Working Papers are those of the author(s) and do not necessarily represent the views of the IMF, its Executive Board, or IMF management.}

\begin{abstract}
The governance structure in global bodies like the IMF continues to be disproportionally dominated by advanced economies. Sustained rapid growth in emerging and developing economies (EDEs) in the past 2-3 decades has led to their growing relative weight in the global economy, but with little increase in their voice in the IMF. The emergence of regional financial arrangements reflects the growing dissatisfaction of the EDEs with the current framework. The global economy is on the cusp of an epochal change moving the fulcrum of economic power from the North Atlantic towards Asia after more than 200 years. This must be recognized and responded to adequately.
\end{abstract}

JEL Classification Numbers: F33, F55

Keywords: Emerging Markets, Global Governance, International Monetary Fund, Quotas

Author’s E-Mail Address: rmohan1948@gmail.com; muneeshkapur@gmail.com

\footnotetext{
${ }^{1}$ The views expressed in the paper are those of the authors and not necessarily those of the institutions to which they belong. Comments on earlier drafts from David Marsh, Mark Sobel, Siddharth Tiwari and staff of the Strategy, Policy and Review (SPR) and Legal Departments of the IMF are gratefully acknowledged; the usual disclaimer applies.
} 


\section{Table of Contents}

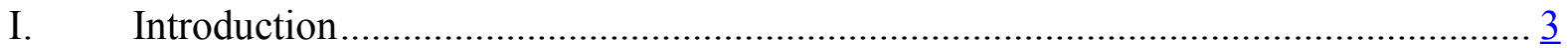

II. Global Economic Shifts: A Long Term View ………............................................ $\underline{5}$

III. Evolution of Global Economic Policy and the Need for Governance .......................... $\underline{9}$

IV. A Chronicle of Quota and Governance Reform at the IMF: A Story of Hesitant but Continuous Change ……………………………………………………………... 15

V. Need for Revision of the Quota Formula............................................................. 37

VI. Emerging Powers and Global Economic Governance: Their Role in Governance in

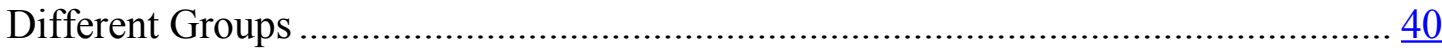

VII. The Way Forward ............................................................................................

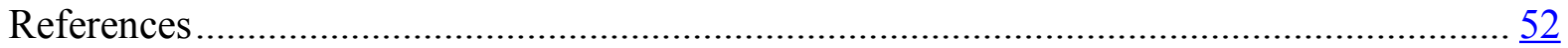

Table 1: Emerging and Developing Economies: GDP and Quota Shares ................................ 7

Table 2: Quota Formula: Variables and Weights Since Inception ........................................ $\frac{18}{20}$

Table 3: General Reviews of Quotas .............................................................................

Table 4: Agreed Changes in IMF Quotas ........................................................................ 22

Table 5: General Reviews of Quotas: Implementation Lags, Participation Threshold and US

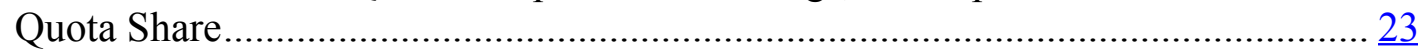

Table 6: Countries with the Largest Quotas: Evolution Since Inception................................ $\frac{27}{44}$

Table 7: Executive Board Composition: Number of Chairs................................................. 44

Table 8: GDP and Quota Shares: Country-wise ……………............................................. 45

Table 9: GDP and Quota Shares: Growing Imbalance ........................................................ 49

Chart 1: Long-Term Growth: Historical Trends …………................................................... $\underline{6}$

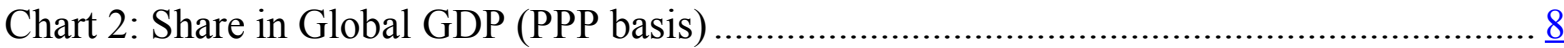

Chart 3: Use of Fund Credit: All Countries ................................................................... $\frac{13}{31}$

Chart 4: Use of Fund Credit: Major Country Groups .......................................................... $\frac{31}{32}$

Chart 5: Use of Fund Credit: Country-wise ………………………………………….... $\frac{32}{33}$

Chart 6: IMF Total Quota Resources ……………………………………………...... $\frac{33}{34}$

Chart 7: IMF Quota Resources and GDP ................................................................... $\frac{34}{35}$

Chart 8: IMF Total Quota Resources and Trade in Goods and Services............................... $\underline{35}$

Chart 9: Projected Structure of the Global Economy (2014-2060) …………………........... $\frac{38}{44}$

Chart 10: European Union: Quotas and GDP (Shares in World Total) ................................... 44 


\section{INTRODUCTION}

Recent years have witnessed an intensified discussion on the need for changes in global economic governance. The discussion has partly been motivated by the stalemate in governance reforms in the International Monetary Fund (IMF), which have been held up despite their approval by its Board of Governors in 2010. The US has 17.7 per cent of quota share (and 16.7 percent of vote share) in the IMF and hence an effective veto over important decisions that require a super majority of 85 per cent of votes. The reforms cannot go ahead because of the inability of the US administration to obtain approval from the US Congress for the reforms. This is ironic since the United States was the principal architect of the 2010 agreement (Truman, 2015), which essentially proposed to marginally reduce the quota shares of European countries in favor of dynamic emerging and developing economies (EDEs). The argument for IMF's governance structure to evolve along with the world economy had been made repeatedly by US Treasury officials since at least 2005, if not earlier (Snow, 2005; Adams, 2005).

Ever since the founding of the IMF such quota reviews are mandated to be undertaken at intervals not exceeding five years. They have, until now, indeed been implemented on a relatively regular basis. As we detail later in this paper, the process has, in general, not been smooth. The advanced economies (AEs) have often resisted the proposed increases in overall IMF quota resources; and it has seldom been easy for US administrations to obtain Congressional approval. Approvals for significant overall expansion for IMF quota resources have usually come under the pressure of international economic and financial crises, or the application of unusual pressure from the IMF management and the rest of its membership. The current delay, now approaching 5 years, is unprecedented, particularly in view of the still fragile nature of the global economy, and IMF's potential need for resources in the light of sovereign debt and other stresses arising from the North Atlantic Financial Crisis (NAFC).

This stalemate assumes greater importance as it is seen to indicate the reluctance of the group of AEs to countenance broader changes in the current framework of global economic governance, despite ongoing significant changes in distribution of economic power in the global economy. The existing framework has been broadly stable since the end of World War II when the Bretton Woods Conference (BWC) led to creation of the IMF and the World Bank. The BWC had also proposed the creation of an International Trade Organization (ITO) which was not agreed to. However, the General Agreement on Tariffs and Trade (GATT) came into being in 1948, and became the World Trade Organization (WTO) in $1994^{2}$. Around the 1960 s, regional development banks were also created to focus

${ }^{2}$ In this context, we may note two other prominent international organizations: the Bank for International Settlements (BIS) and the Organization for Economic Co-operation and Development (OECD). The BIS, established in 1930, is the world's oldest international financial organization, and its current 60 member central banks make about 95 percent of world GDP. The mission of the BIS is to serve central banks in their pursuit of monetary and financial stability, to foster international cooperation in those areas and to act as a bank for central banks. The OECD was formed in 1961 as a successor to the Organization for European Economic Cooperation

(continued...) 
on the development needs of the specific regions: Inter-American Development Bank (1959), African Development Bank (1964) and Asian Development Bank (1966). Since then, the only significant addition to this framework of global economic institutions is the Financial Stability Board (FSB), which was created in 2009 as a consequence of the NAFC.

The issue at hand is the continuous domination of these organizations by the AEs despite the momentous changes now taking place in the composition of the global economy. The ongoing creation of new institutions led by EDEs, particularly by the BRICS countries (Brazil, Russia, India, China and South Africa) is indicative of the dissatisfaction of these countries with the current framework of global economic governance.

Why is this discussion taking place with greater force today than, say 10, 15 or 20 years ago? We argue that we are indeed on the cusp of an epochal change in terms of economic power, the type of which has not been witnessed in the past 200-250 years. Furthermore, the global economic structure was broadly stable from the end of World War II till the turn of the millennium. The share of the AEs in global GDP was around 60-70 per cent right through that period though, of course, there were inter se changes in relative weights among the AEs themselves, particularly related to the post war economic rise of Germany and Japan. However, the economic dominance of the United States has been undiminished throughout the period. The pace of change since 2000 has, however, accelerated with the fulcrum of economic weight rapidly shifting from the North Atlantic to Asia after more than 200 years. It is this dramatic development becoming manifest in the past 15 years that is fueling the current vigorous debate. With the expectation of such change accelerating further over at least the next couple of decades, changes in global economic governance will have to be more substantive than the current incremental change envisaged.

Although we draw attention to the broader issues of overall global economic governance, we focus on governance of the IMF in particular. The paper first (Section II) takes a long term view of the momentous shifts that have taken place in the global economy over time. In section III, we make a case for the need for global economic governance at the present time. Section IV provides a historical view of the changes that have taken place in the IMF resources and governance structure over the 70 years of the IMF's existence. Section $\mathrm{V}$ provides the rationale for the need for revising the quota formula that would better reflect the ongoing changes in the global economy. An assessment of broader global international economic policy making and coordination and the role of EDEs in the various global forums is undertaken in Section VI. We conclude by discussing the imperatives of change necessary on an ongoing basis so that the IMF can continue to be effective and credible as the key global institution promoting global financial stability and lender of last resort.

(OEEC). The OECC was established in 1948 to run the US-financed Marshall Plan for reconstruction of a continent ravaged by war. Encouraged by its success and the prospect of carrying its work forward on a global stage, Canada and the US joined OEEC members in signing the new OECD Convention in 1960 and the OECD was officially born in 1961. Today, the OECD has 34 member countries, mostly advanced economies. However, five major emerging economies - Brazil, India, China, Indonesia and South Africa - given their increasing weight in the global economy are now 'Key Partners' of the OECD. These 39 countries account for 80 percent of world trade and investment, giving the OECD a pivotal role in addressing the challenges facing the world economy. 


\section{Global Economic Shifts: A Long Term VieW}

A long term historical view of the global economy indicates that epochal changes took place at the turn of the $18^{\text {th }}$ and $19^{\text {th }}$ centuries with the onset of the industrial revolution in Europe. Economic activity gathered pace in what we now call the industrial or advanced economies, particularly in Europe, with the US and Japan following in the $19^{\text {th }}$ century. Asian, African and Latin American countries stagnated during the whole period till the midtwentieth century. Whereas the per capita incomes of Asian countries were broadly comparable to that of the US prior to 1800, the gap increased inexorably till about 1950 . The ratio of US per capita income to that of Asian countries jumped from around 2 in 1800 to around 13 by 1950 . In 1950, the ratio was even higher at around 21 vis-à-vis the Chinese economy (Chart 1).

The world was thus increasingly divided into rich and poor. This period was also marked by a rising degree of colonialism and imperialism. Economic power rotated among the industrial countries - initially to the United Kingdom and other European countries till World War I and subsequently to the US. Europe was in the ascendant from the onset of the industrial revolution until World War I. Much of the world now classified as developing or emerging, was divided up as colonies of European powers. The political and economic ravages of World War I in Europe began the process of transfer of power to a reluctant United States. The League of Nations was effectively stillborn with the US Congress refusing to ratify the treaty promoted by its own President, Woodrow Wilson, and a situation reminiscent of the current stalemate with regard to IMF reform. The confusion of the interwar period, and the ensuing Second World War further weakened Europe. Finally, after World War II, the United States emerged as the clearly dominant economic, political and military power, though the Soviet Union remained as a credible competing military power. The economic and political dominance of the United States became even more complete after the fall of the Soviet Union.

Since the 1950s, global growth dynamics have changed, with stronger growth in Asian and Latin American economies. The ratio of per capita income of the US to Asia is now close to 5:1, a dramatic reduction from 13:1 witnessed as recently as in 1950. Economic power is, thus, shifting away from the advanced Western industrial economies to the rest of the global economy, especially the fast-growing emerging economies. It is these significant economic developments and their implications for global economic governance that motivate this paper.

The first phase of high growth in Asia came from Japan beginning in the 1950s. As a consequence, Japan was inducted relatively rapidly into the group of AEs, the G-7, and, replacing India, was also given an 'appointed' seat in the IMF's Executive Board in 1972. The growth momentum spread to Korea, Singapore, Taiwan, and Hong Kong - the Asian Tigers - during the 1960s and beyond.. These economies started growing even faster than Japan at its peak rate of growth and their incomes started converging to European and North American levels (Chart 1). Notwithstanding the almost unprecedented high growth for nearly two decades, the economic weight of the Asian Tigers in the global economy remained relatively low, and this trend was accentuated by the stagnation in Japanese growth in the early 1990s. Thus, their commendable growth record, although lauded by economists, did not 
lead to any re-ordering of global economic governance, given their relatively small share in global GDP.

\section{Chart 1: Long-Term Growth: Historical Trends}

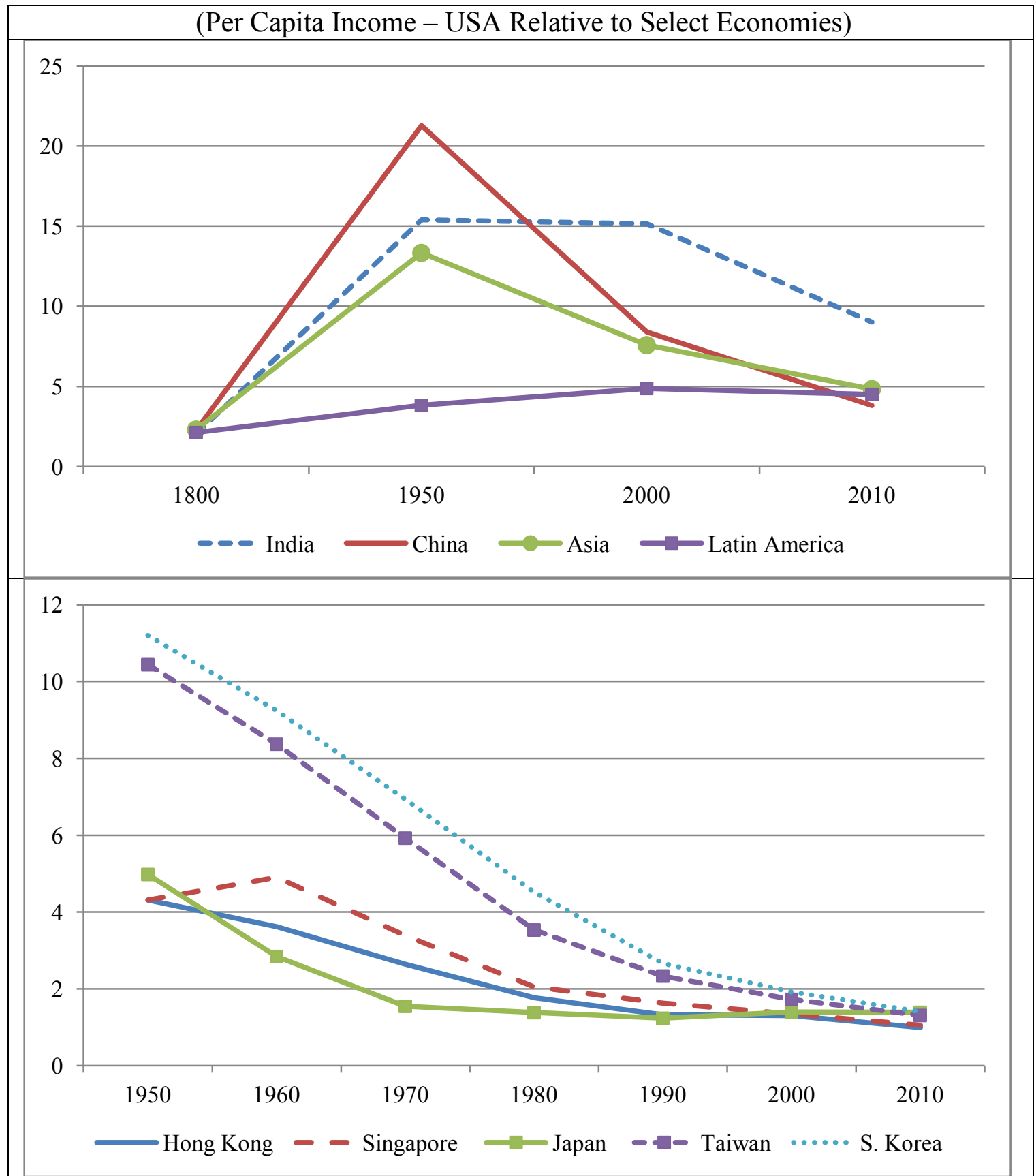

Note: y-axis measures per capita GDP of USA relative to the selected economies.

Source: Bolt and van Zanden (2013).

The Asian growth miracle, however, became more conspicuous beginning in the 1980s, with the initiation of structural reforms in Asia's two largest economies - China beginning the 1980s and India beginning the 1990s. Both of these economies, in particular 
China, have now recorded close to 3 decades of high growth: annual real GDP growth during 1980-2014 averaged over 6 percent for India and almost 10 percent for China. The 1990s and 2000s also witnessed a phase of high growth with relative macroeconomic stability in the Latin American region, and the larger economies like Brazil attracted interest. Given their large initial economic size, and sustained high growth, the BRICS countries now have a combined weight of 31 percent in global GDP (PPP basis) - up significantly from only 17 percent in 1992 - and are hence major players in the global economy. According to the IMF estimates (IMF, 2015a), the share of the BRICS is expected to increase further to 33 percent by 2020. By 2017, the share of the BRICS will exceed that of the G7. Even in terms of market exchange rates (MER), the share of BRICS in global GDP, at about 21 per cent, is comparable to that of the US at 22 per cent and the European Union at 24 per cent [Chart 2].

What is notable is that despite high growth in Asia over the 1970s, 1980s and 1990s, there was little palpable change in the EDEs' overall economic weight in the world, increasing from around 30 per cent in the mid-1960s to just over 40 per cent by 2000 in terms of global GDP (PPP basis). In market exchange rate (MER) terms, their weight actually fell from just over 25 per cent in the mid-1960s to about 20 per cent around 2000 (Table 1). The weight of AEs remained at about 60-70 per cent in PPP terms and 75-80 per cent at market exchange rates until 2000. Thus, there could be little argument about their dominance in global economic structure, and the contours of global economic governance could easily be decided among themselves, essentially within the G10 or G7.

Table 1: Emerging and Developing Economies: GDP and Quota Shares

\begin{tabular}{|c|c|c|c|c|c|c|c|c|c|c|c|c|}
\hline Item & 1948 & 1959 & 1966 & 1970 & 1978 & 1980 & 1983 & 1992 & 1999 & 2011 & 2014 & 2020 \\
\hline \multicolumn{13}{|c|}{ Share in global GDP (PPP basis) } \\
\hline EDEs & n.a. & n.a. & 30.8 & 32.3 & 36.1 & 36.1 & 36.2 & 41.4 & 42.2 & 54.6 & 56.9 & 60.7 \\
\hline EDEs plus & n.a. & n.a. & n.a. & n.a. & n.a. & n.a. & n.a. & n.a. & n.a. & 57.3 & 59.5 & 63.3 \\
\hline \multicolumn{13}{|c|}{ Share in global GDP (market exchange rates basis) } \\
\hline EDEs & n.a. & n.a. & 26.5 & 25.6 & 22.9 & 24.9 & 23.3 & 16.7 & 19.2 & 36.4 & 39.1 & 43.3 \\
\hline EDEs plus & n.a. & n.a. & n.a. & n.a. & n.a. & n.a. & n.a. & n.a. & 21.4 & 39.0 & 41.9 & 46.2 \\
\hline \multicolumn{13}{|c|}{ Share in IMF Quota } \\
\hline EDEs & 22.4 & 21.9 & 26.6 & 28.0 & 33.5 & 35.1 & 34.5 & 36.0 & 35.5 & 36.6 & 36.6 & n.a. \\
\hline EDEs plus & 22.4 & 21.9 & 26.9 & 28.3 & 34.1 & 35.7 & 35.2 & 37.0 & 37.5 & 39.5 & $\begin{array}{r}39.5 \\
(42.4) @\end{array}$ & n.a. \\
\hline
\end{tabular}

Memo:

\begin{tabular}{llllllllllll} 
Member C & 43 & 67 & 103 & 113 & 134 & 138 & 143 & 171 & 182 & 187 & 188 \\
\hline
\end{tabular}

Note:

"EDEs plus 8" includes the following additional 8 countries to the WEO/IFS classification of EDEs: Czech Republic, Estonia, Korea, Latvia, Malta, Singapore, Slovak Republic and Slovenia. These eight countries are included in the group of EDEs in the quota papers, but are considered as "advanced economies" in the WEO/IFS classification.

(a): Quota shares once the 2010 reforms $\left(14^{\text {th }}\right.$ Review $)$ are implemented.

The years in the table are in which the quota increases under the general/ad hoc reviews became effective.

Data for 2020 are IMF projections.

Source: World Economic Outlook Database (April 2015), IMF; International Financial Statistics, IMF

As the growth momentum of a number of large EDEs continued over the 2000s, and as they achieved significant weight in the global economy, the pace of relative change in global economic shares began to accelerate. Thus, the share of EDEs in global GDP is expected to increase from about 40 per cent in 2000 to over 60 per cent by 2020 in PPP terms 
and from 20 to 40 per cent in MER terms. Similarly, the share of G7 countries in global GDP (PPP) is expected to fall from about 44 per cent in 2000 to about 30 per cent by 2020 , with a corresponding increase in the share of BRICS from 19 per cent in 2000 to 33 per cent in 2020. [Chart 2].

\section{Chart 2: Share in Global GDP (PPP basis)}

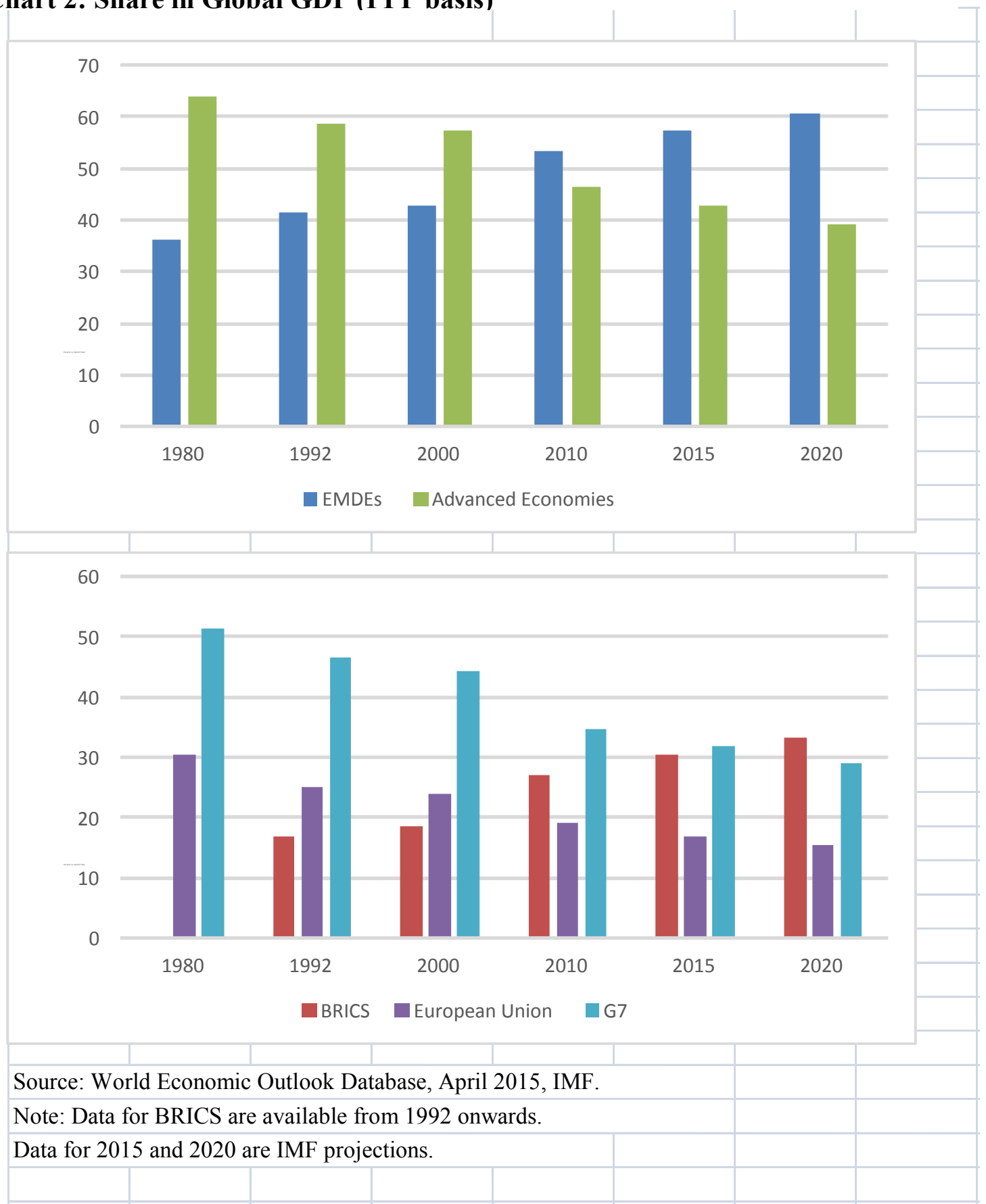


This very rapid change in economic power between the G7 on the one hand, and the BRICS on the other, over just a span of 20 years is dramatic. It is reversing the economic hegemony enjoyed by Europe and North America for over 200 years and can hence be regarded as the beginning of an epochal change. It is no wonder then, that given the relative growth dynamics over the past 2-3 decades and the projected trajectories, there is a demand for better representation of the EDEs in the global economy and in the major global economic institutions like the IMF and the World Bank. The demand for better representation also needs to be viewed against the backdrop of the NAFC that originated with the sub-prime troubles in the US in mid-2007. The NAFC has led to a prolonged period of stagnation/weak growth in the mature economies since 2009, whereas the EDEs have continued to record strong growth, albeit with some moderation more recently. The NAFC has hastened the shift of economic weight towards the EDEs. However, high growth in the EDEs notwithstanding, we do need to recognize that their per capita income levels are still well below those in the AEs and this is especially true for the largest EDEs i.e., China and India.

Greater participation in global economic governance by the EDEs will also require greater assumption of responsibility. The US and Europe clearly continue to exhibit far superior soft power in terms of their economic institutions, including universities and research centers. Thus, the transfer of governance roles according to economic weight will need to be tempered by the relative lack of sophistication and size of economic institutions in these aspiring countries. But we can confidently expect that this gap will also be bridged before too long.

\section{Evolution of Global Economic Policy and the Need for Governance}

As we discuss the changing weight of EDEs in global economic governance, it is relevant to ask why we continue to need these international institutions. After all, the world did without such institutions before the Bretton Woods institutions. Why is it important for the IMF to exist and continue to be credible, effective and seen to be legitimate? To examine this question, it is necessary to do a quick recap of the evolution of global economic policy, and why the current framework needs a coordinating institution.

Over the last century or so, the global economy has evolved continuously reflecting ongoing changes in global economic realities and in economic thought in search of an anchor (Benassy-Quere and Pisani-Ferry, 2011). The gold standard provided the anchor to the global economy in the pre-World War I period: this period was characterized by free capital flows and fixed exchange rates and hence no independent monetary policy. But, the successful pursuit of the gold standard required implicit global cooperation among the major global economic powers of the time - this was perhaps not as difficult as it might be now since it had to be done within a relatively small group comprising of the European countries and North America. The rest of the world did not matter and was, in any case, under colonial domination. The system, however, broke down during the inter-war period: the Great Depression, beggar-thy-neighbor and protectionist policies, hyperinflation in Germany, and ascendancy of fiscal policy characterized the interwar years. This period of global economic chaos provided an impetus towards developing a robust global economic order for high and stable growth. The Bretton Woods conference, in the mid-1940s, dominated by the US and

UK, provided a forum for these discussions, which culminated in the creation of three major 
international financial institutions - namely, the IMF, the World Bank and later, GATT and the WTO.

On the international monetary side, the gold standard of the pre-World War I phase yielded to the Bretton Woods system of semi-fixed exchange rates and controlled capital flows during the 1950s and 1960s, which provided scope for independent monetary policies. But this new framework needed an institution for taking up the responsibility for effective oversight of this new international monetary system: the International Monetary Fund $(\mathrm{IMF})^{3}$.

Although an attempt was made after World War I to put in place a framework for global governance through the Treaty of Versailles and setting up of the League of Nations, there was little attention given to the need for institutions for global economic governance. Perhaps "neglect of economics occurred largely because limitations of the invisible hand were not well understood" (Boughton, 2011)! For a generation or more, the international gold standard had provided a measure of stability with little need for overt cooperation. Thus, there was no consideration at that time for setting up international institutions for promoting international economic and financial stability.

The problems caused by rigidly fixed exchange rates caused by adherence to the gold standard, and that of global liquidity being limited by gold supplies, got understood and led to the founding of the Bretton Woods system of fixed but adjustable exchange rates. If exchange rates were to be adjustable, it had to be ensured that they did not lead to beggar thy neighbor policies. This needed some international cooperation and the need for an international monitor: the International Monetary Fund ${ }^{4}$. That the Bretton Woods

\footnotetext{
${ }^{3}$ The purpose for the setting up of the IMF, according to its Articles of Agreement, is:

i. To promote international monetary cooperation through a permanent institution which provides the machinery for consultation and collaboration on international monetary problems.

ii. To facilitate the expansion and balanced growth of international trade, and to contribute thereby to the promotion and maintenance of high levels of employment and real income and to the development of the productive resources of all members as primary objectives of economic policy.

iii. To promote exchange stability, to maintain orderly exchange arrangements among members, and to avoid competitive exchange depreciation.

iv. To assist in the establishment of a multilateral system of payments in respect of current transactions between members and in the elimination of foreign exchange restrictions which hamper the growth of world trade.

v. To give confidence to members by making the general resources of the Fund temporarily available to them under adequate safeguards, thus providing them with opportunity to correct maladjustments in their balance of payments without resorting to measures destructive of national or international prosperity.

vi. In accordance with the above, to shorten the duration and lessen the degree of disequilibrium in the international balances of payments of members.
}

${ }^{4}$ The Bank for International Settlements (BIS), which had existed since 1930, could have possibly been a contender for this responsibility, but it was ruled out by the Bretton Woods conference resolution calling for the abolition of the BIS "at the earliest possible moment", on the grounds that the BIS would have no useful role to play once the newly created World Bank and International Monetary Fund were operational. The European central bankers held a different opinion, and successfully lobbied for maintaining the BIS. The BIS accordingly restricted its focus on the European monetary and financial matters during the 1950s, but gradually emerged

(continued...) 
institutions, the IMF and the World Bank, got based in Washington D.C., and the United Nations in New York City, also signaled the transfer of both economic and political power from Europe to the United States.

The 1950s and 1960s witnessed the group of developing countries generally adopting the Bretton Woods policies of fixed, but adjustable, exchange rates and capital controls, along with import substitution policies to develop their industrial sectors. The import substitution policies yielded to export-promotion policies beginning in the $1960 \mathrm{~s}$, as the initial pessimism about the ability of the developing countries to be successful exporters waned. This was influenced by the successful experiences of Japan during the 1950s and 1960s and the Asian Tigers (Korea, Singapore, Hong Kong and Taiwan) during the 1960s and 1970s and subsequently the Asian Cubs (Thailand, Indonesia, and Malaysia) with exportoriented policies and stronger growth.

The Bretton Woods system, however, collapsed in the early 1970s, reflecting in part expansionary macroeconomic policies in the US, which led to questions over the sustainability of the US dollar's convertibility to gold at a fixed exchange rate. The collapse of the Bretton Woods system led to the introduction of the currently prevailing system of floating exchange rates, relatively more open capital accounts and independent monetary policy in the major AEs.

The 1980s saw further changes in global economic dynamics and thought, driven by the pro-market policies of the Thatcher and the Reagan years in the UK and the US, respectively, and the emergence of the so called "Washington Consensus". The collapse of the Iron Curtain, and the Soviet Union provided a further push to market-oriented policies and capitalism, and opening up of capital accounts and financial markets to non-residents. Within this post-Bretton Woods framework, the monetary policy framework transited initially to monetary targeting regimes in the 1970s and 1980s in a number of economies, and then to inflation targeting type frameworks in the 1990s and 2000s. Given the preference for open capital accounts, and the belief in efficient financial markets, financial sector regulation moved from an intrusive to a light touch framework.

When the IMF was founded, international financial flows were mainly related to trade financing: private sector financial flows were of limited scope and importance. Indeed, the Bretton Woods system did not envisage free capital flows and Article VI of the IMF Articles of Agreement empowered the IMF to prohibit capital outflows from countries when necessary. Balance of payments problems were to be solved by orderly exchange rate adjustments governed by the IMF. Thus, until the 1970s, the number of financial, banking and debt crises was few: in fact, the drawal of IMF resources by member countries was limited to 100 per cent of their respective quotas, and only 25 per cent in one year. It was only subsequent to the breakdown of the Bretton Woods system that access limits to the use

into a global international financial organization beginning the 1960s, focusing on central banking related issues. 
of IMF resources began to be increased significantly, though some change had taken place in the 1960s and the 100 per cent limit had been increased to 150 per cent with the initiation of the Compensatory Financing Facility (CFF).

With the breakdown of the Bretton Woods System in 1973, and the advent of floating exchange rates and free private capital flows, and the oil price rises of 1973 and 1979, the frequency and seriousness of financial crises also increased. Between 1970 and 2011, there were 147 systemic banking crises, 218 currency crises, and 66 sovereign debt crises (Boorman, 2015). Until 2007, the vast majority of these crises occurred in the EDEs; interestingly, in the 1950s and 1960s, a number of prominent AEs were also forced to access IMF financing, a fact that is typically not recognized nowadays. Thus, in the popular perception, the IMF member countries got grouped in two relatively distinct groups, debtor countries (mostly EDEs) and creditor countries (mostly AEs), and it was therefore natural that AEs would have a more dominant governance role. These distinctions were blurred at times, but have become more so since the advent of the NAFC. There have been more than 20 systemic banking crises since 2008, the majority of them being in AEs. Consequently, many EDEs are now counted among the group of creditor countries, and AEs among the debtor countries group. The incidence of banking, exchange rate and sovereign debt crises was very low during the Bretton Woods System of fixed but adjustable exchange rates. The greater frequency of crises in the post-Bretton Woods period has brought to the center stage the increasing role of the IMF as a lender of last resort and consequent arbiter of economic policies, and hence a lead role in the framework of global economic governance.

Thus, the functions of the IMF changed along with changes in global trends in economic orthodoxy and policies, and with the increasing frequency of crises. The initial need for the IMF arose as the world went off the gold standard and moved to a modified gold/dollar standard with fixed but adjustable exchange rates. After the breakdown of the Bretton Woods arrangements in 1973, as economic orthodoxy moved to floating exchange rates and freer capital flows, global monetary policy lost its previous anchors and countries could pursue independent monetary policies. But with the consistent expansion of trade with the graded success of GATT and WTO over the years, along with increasing cross border private capital flows often financing the sovereign debt needed for expansionary fiscal policy in many countries as also the continued liberalization of policies to attract private capital flows, the frequency of banking, exchange rate and sovereign debt crises rose. The need for IMF assistance increased correspondingly. The financial needs of countries in crisis also rose and access limits rose accordingly to almost 600 per cent of quota in 1981. Exceptional access was invoked 11 times in the 1990s, with the Korean program of 1998 going up to 2000 per cent of the country's quota. In the NAFC, the utilization of access limits greater than 1000 per cent has been routine for a number of European economies, both those in transition, like Hungary, Latvia, Ukraine, Romania and AEs like Iceland, Greece, Portugal and Ireland [Chart 3].

Thus, as the global economic, monetary and financial systems have evolved over the IMF's history of 70 years and as dominant western economic policy orthodoxy has changed, so has the role of the IMF. With the ongoing changes in technology in the 1990s and beyond, and much freer capital flows, opening of capital accounts and overall financial liberalization in AEs and EDEs alike, financial interconnectedness has meant ever larger 
sizes of rescue programs. Whereas, in 1981, India needed a program of less than US\$ 5 billion to solve its balance of payments crisis at that time, the recent IMF programs for small countries like Portugal, Ireland and Greece have each exceeded US\$ 25 billion. In fact, the need of these countries has been so large that IMF resources have had to be supplemented by European institutions: so much so that the IMF has been much the junior partner in these programs in terms of resources, and possibly in program design. The recent and ongoing developments in Greece have brought in focus some of these issues.

\section{Chart 3: Use of Fund Credit: All Countries}

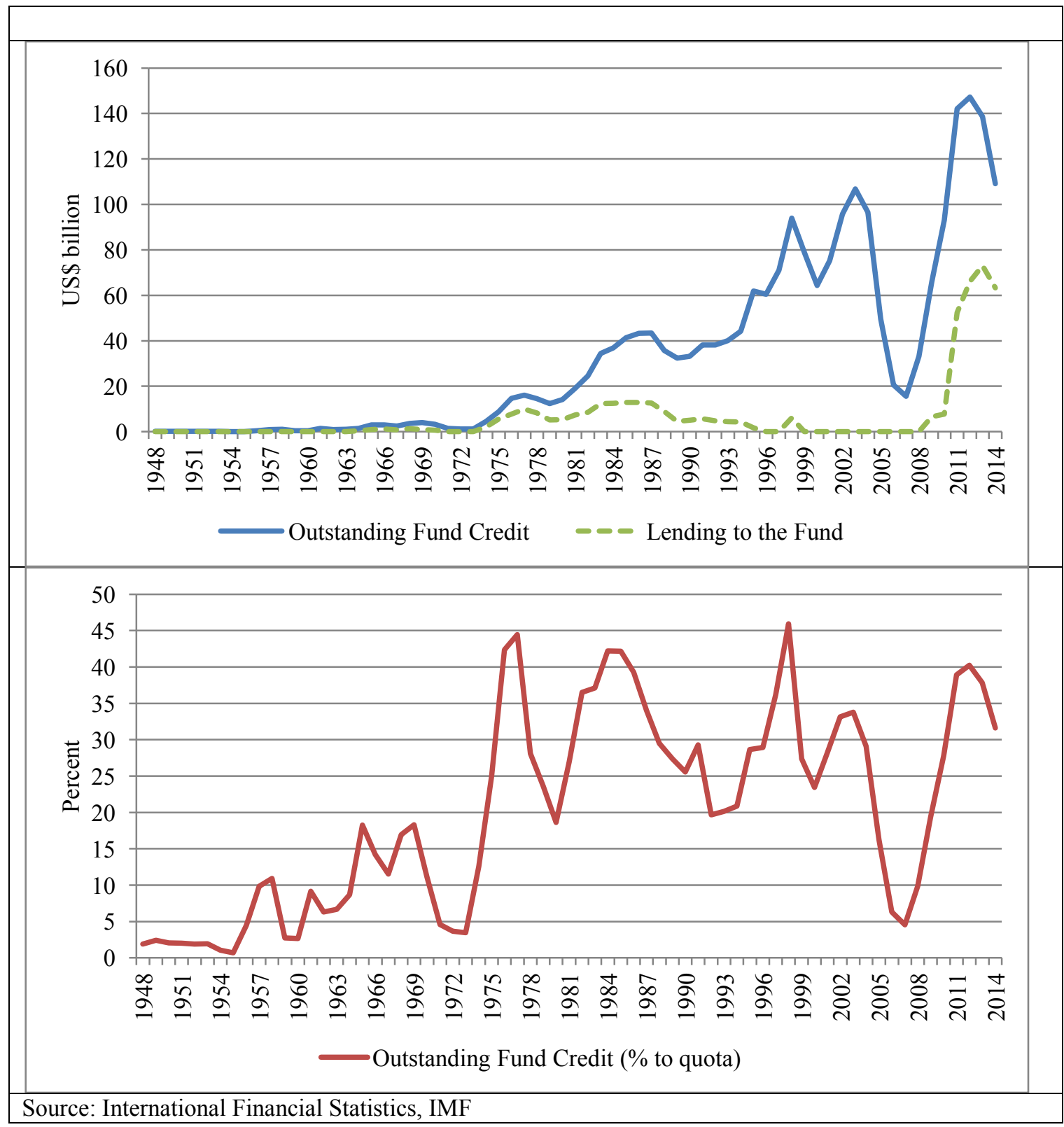

The NAFC has called into question the dominant economic paradigm - characterized by the Washington Consensus of free cross-border capital flows, fully flexible exchange 
rates, and complete faith in the efficacy of markets and capitalism. It also raised questions on the dominant paradigm of macroeconomic management for central banks - inflation targeting. Inflation targeting regimes led to central banks focusing only on a narrow objective (price stability defined low and stable inflation rates) for monetary policy supported by a single instrument (policy interest rate). In the process, other key complementary central banking responsibilities - like financial regulation and supervision and public debt management - were either entrusted to specialized authorities outside the central bank or deemphasized. Strong micro-prudential supervision was believed to contribute to effective financial stability at the macro level. This regime was associated with the Great Moderation low and stable inflation in conjunction reduced volatility in output - for nearly two decades. But, this period also witnessed financial imbalances building up in the global economy, ultimately ending up with the NAFC - the severest financial crisis since the Great Depression. In this context, it is puzzling - and, in fact, incorrect - that the NAFC is often dubbed as a global financial crisis, although it originated and hit only the North Atlantic economies of the US and Europe. The EDEs were not a source of the current crisis, although they were also hit by the NAFC, given the strong trade and financial linkages. It is, therefore, a misnomer to call the 2008-09 crisis as a global financial crisis, even as the various financial crises over the past two decades have been typically prefixed by the region where the crisis initiated - for example, the Mexican tequila crisis, the Asian financial crisis and the Russian crisis during the 1990s.

In the aftermath of the NAFC, it has been recognized that central banks have a key role to play not only in maintaining price stability but also in fostering financial stability. Issues relating to financial stability and the institutional arrangements thereof have attracted interest in the post-NAFC period. The UK, which had taken the lead in separating financial regulation and supervision from the central bank in the 1990s, has again led in reversing its earlier decision by returning responsibility for financial regulation and supervision back to the Bank of England. In a number of other countries too, the regulatory architecture is being revisited and central banks are being given responsibility for financial sector regulation and financial stability. Other AEs are similarly integrating prudential functions into the central bank, including the European Central Bank and the US Federal Reserve. Accordingly, the role of the IMF has increased in promoting the adoption of international procedures and standards in regulatory institutions in the interest of financial stability. After the NAFC, the IMF/World Bank are now tasked to carry out mandatory Financial Sector Assessment Programs (FSAPs) for the 20 systemically important countries.

Although a great deal of thinking is going on the desirable contours of global economic governance, particularly relating to financial regulation, financial globalization is unlikely to be reversed. As the world recovers from the NAFC, there can be no doubt that financial crises will erupt in the coming years and decades in various parts of the world, both emerging and advanced. As the size of EDEs has grown individually and collectively, and given the growing financial interconnectedness, the resolution of each crisis is likely to need large international resources.

It is in this context that the need for the IMF is likely to be enhanced rather than reduced. After the very active role of the IMF in the resolution of Latin American debt crises in the 1980s, the Mexican, Russian, Turkish and Asian crises in the 1990s, there was a lull in 
crises for almost a decade till the NAFC. Consequently, complacency had set in and no increase took place in the IMF quota resources for a decade between 1998 and 2008. Hence, when the NAFC broke, the IMF had to resort to large borrowings through the New Arrangements to Borrow (NAB) and later through the Bilateral Arrangements. In fact, the level of complacency and lack of effective surveillance of the global economy at that time is also illustrated by the fact that IMF staff were cut substantially during 2008-09: the number of professional and managerial staff fell from 2005 in April 2007 to 1862 by April 2009. The downsizing exercise led to a reduction of 492 in the staff strength, including 286 professionals (grades A9-B5) (IMF, 2009).

This experience illustrates the importance of strengthening the IMF for its role in contributing to financial stability in the world in future and in its role as lender of last resort. For it to perform this role effectively, it must have credibility along with perceived legitimacy. With the dramatic change that has already taken place in the structure of the global economy since the turn of the century, and the expected acceleration of this change in the same direction in the medium term future, it is essential that the emerging powers get their rightful share in the IMF's governance accordingly. Such changes will have to be reflected in the internal governance of the IMF in terms of quotas as well as in voice in the Executive Board, and will have to go far beyond the current staff review. What is also important in this context is that, among the AEs, the United States will retain its dominant position, while that of Europe is likely to decline. Apart from its continued high economic weight, the soft power of the US in terms of its institutional strength will remain especially dominant. It is therefore essential for the US to retain its important role in IMF governance, even as that of EDEs increases.

\section{A Chronicle OF QuOTA AND Governance ReForm AT THE IMF: A STORY OF Hesitant but Continuous Change}

The original intention of the IMF's founding fathers was for it to be inclusive in its membership so that the global economic monitoring system could be managed effectively in a neutral manner. However, this objective of inclusive membership took almost six decades to achieve. The IMF started with 40 original members. The Axis powers - Germany, Italy, Spain, and Japan - were excluded in the beginning but joined over time during the 1950s. Most of Africa was still colonized and was deemed ineligible for membership, though India, while still a colony till August 1947, was included among the founding members. The Soviet Union, despite being a participant in the Bretton Woods deliberations did not eventually join. China was a founding member, but its seat went to Taiwan, Republic of China, in 1950 in the aftermath of the communist victory. The Soviet Union's allies withdrew (Poland in 1950) or were required to withdraw (Czechoslovakia in 1954). These countries rejoined after 1990. So, from the beginning of the institution until the Iron Curtain came down, no socialist country had been included in the IMF and the World Bank (except Yugoslavia).. The governance of the Fund was effectively dominated by North America and Western European countries.

The Fund's membership nearly doubled during the 1960s and the 1970s - from 69 in 1960 to 138 in 1978 - with decolonization and the joining of the newly independent African

nations. The inclusion process got strengthened further with the IMF's decision in 1980 to 
finally recognize the People's Republic of China (PRC), rather the Republic of China, based in Taipei, as the government of China. The 1980 decision involved neither the admission of a new member nor the termination of an existing membership but only the recognition of a different government to represent the member (Boughton, 2011). The next major boost to the Fund's membership came during the early 1990s, with the joining of Russia, other countries in the Commonwealth of Independent States and other Eastern European countries, following the break-down of the erstwhile Soviet Union. Thus, by the early 1990s, the Fund's membership had expanded significantly making it a truly global institution with universal membership, though no commensurate change took place in its overall governance.

Each member of the IMF is assigned a quota which then determines its voting power as well as its capacity to borrow. For the Fund as a whole, quotas are expected to provide durable and sufficient funds for lending to members. Since its inception, the allocation of quotas to members has been, in principle, based on formulae, which have been continuously refined over time. However, these formulae are actually just used as starting points and the actual quotas have been a complex outcome of laborious negotiations. Selective and ad hoc increases have also been implemented for subsets of members at different times.

The quota formulae became increasingly complicated over time. The original single formula multiplied to 10 different formulae in 1962-63, with five formulae based on merchandise exports and imports and another five based on current receipts and payments. The complexity was reduced, but only somewhat in 1983, when the number of formulae was halved to 5; this was an outcome of dropping the formulae based on merchandise trade. This level of complexity continued till 2008 , when the Board was finally able to agree on a new relatively simple formula (Table 2). The current formula, though simple, continues to suffer from serious flaws, as discussed later.

The initial quotas in 1944, when the IMF was set up, were supposed to have been based on the original formula, but it appears that the quotas were actually decided ex-ante and the quota formula was developed ex-post to rationalize and justify the quotas (IMF, 2000; Mikesell, 1994; Mirakhor and Zaidi, 2006; Virmani and Patra, 2011). The US Treasury staff were instructed to prepare a formula that would give the largest quotas to the US and its three then allies (the UK, the USSR, and China) - President Roosevelt's Big Four'. A purpose of the formula was also to dilute the effect of the US in the world economy so as to distribute the quota more widely to make the IMF appear to be more international. Given these dynamics, the quotas of many similarly placed countries, in terms of economic weights and other relevant economic data, turned out to be different from what was expected, which

\footnotetext{
5 "In mid-April 1943, shortly after the White plan was made public, White called me to his office and asked that I prepare a formula for the ISF [International Stabilization Fund] quotas that would be based on the members' gold and dollar holdings, national incomes, and foreign trade. He gave no instructions on the weights to be used, but I was to give the United States a quota of approximately $\$ 2.9$ billion; the United Kingdom (including its colonies), about half the U .S. quota; the Soviet Union, an amount just under that of the United Kingdom; and China, somewhat less. He also wanted the total of the quotas to be about $\$ 10$ billion. White's major concern was that our military allies (President Roosevelt's Big Four) should have the largest quotas, with a ranking on which the president and the secretary of state had agreed. I was surprised that White did not mention France, which was usually regarded as being third in economic importance among the Allied powers. He said he did not care where France ranked, and its ranking did not need to be an objective in the exercise." (Mikesell, 1994, p. 22)
} 
led some country delegations to question the basis for the allocations. During the Bretton Woods conference in 1944, the quota formula was not disclosed to the members, despite repeated requests from many of them. A number of delegations - Australia, France, India and Iran - entered their reservations on record against the allocation process (Mikesell, 1994). The quota formula was apparently released to the public for the first time in 1956. Accordingly, as could be expected, the first decade was marked by continuous requests from some members for an increase in their quotas, as they felt that their allocated quotas were not commensurate with their economic power (de Vries and Horsefield, 1969).

Members' quota shares became relatively more important over time, given that their borrowing limits were linked to their quotas and as the need arose for drawal of funds from the IMF. Quota shares assumed further significance in the late 1960s, when Special Drawing Rights (SDRs) were invented and SDR allocations were also linked to the quotas (de Vries, 1976). Most importantly, the persistent divergences in the GDP growth rates across members led to demand for a more dynamic adjustment in the relative quotas of members. Continued growth differences contributed to increased relative weights in global GDP of fast-growing economies such as Japan and Germany during the 1950s and 1960s, mirrored by the declining weight of then slow growing countries such as India and China. We are now witnessing a reversal of this process, with the growth in the EDEs outpacing the AEs.

Along with the distribution of quota shares, there has been a lively debate on the overall size of the quota resources during all the fourteen general reviews so far. The need for higher quotas has been necessitated by the continuous increase in underlying economic activity, along with a relatively faster growth in international transactions amidst continued opening up of trade and capital accounts: relaxation of import controls in the 1950s, the assumption of convertibility obligations in 1958, and the increased mobility of capital during the 1960s and ensuing decades, with particular acceleration in the 1990s and 2000s.

The AEs have typically favored either no increase or a modest increase (25-50 percent) in the overall size of the quotas in each of the successive reviews for a variety of reasons: existence of private international markets; limitations on their own ability to provide resources in the 1970s; and concerns related to such increases being inflationary. The EDEs have, on the other hand, preferred a relatively larger increase in quotas (75-100 percent) in view of the increased external financing needs from the potential shocks from the growing trade and financial interconnectedness (de Vries, 1976, 1985). It could be said that the potential debtor countries generally wanted large increases in IMF quota resources while the creditor countries resisted them. 
Table 2: Quota Formula: Variables and Weights Since Inception

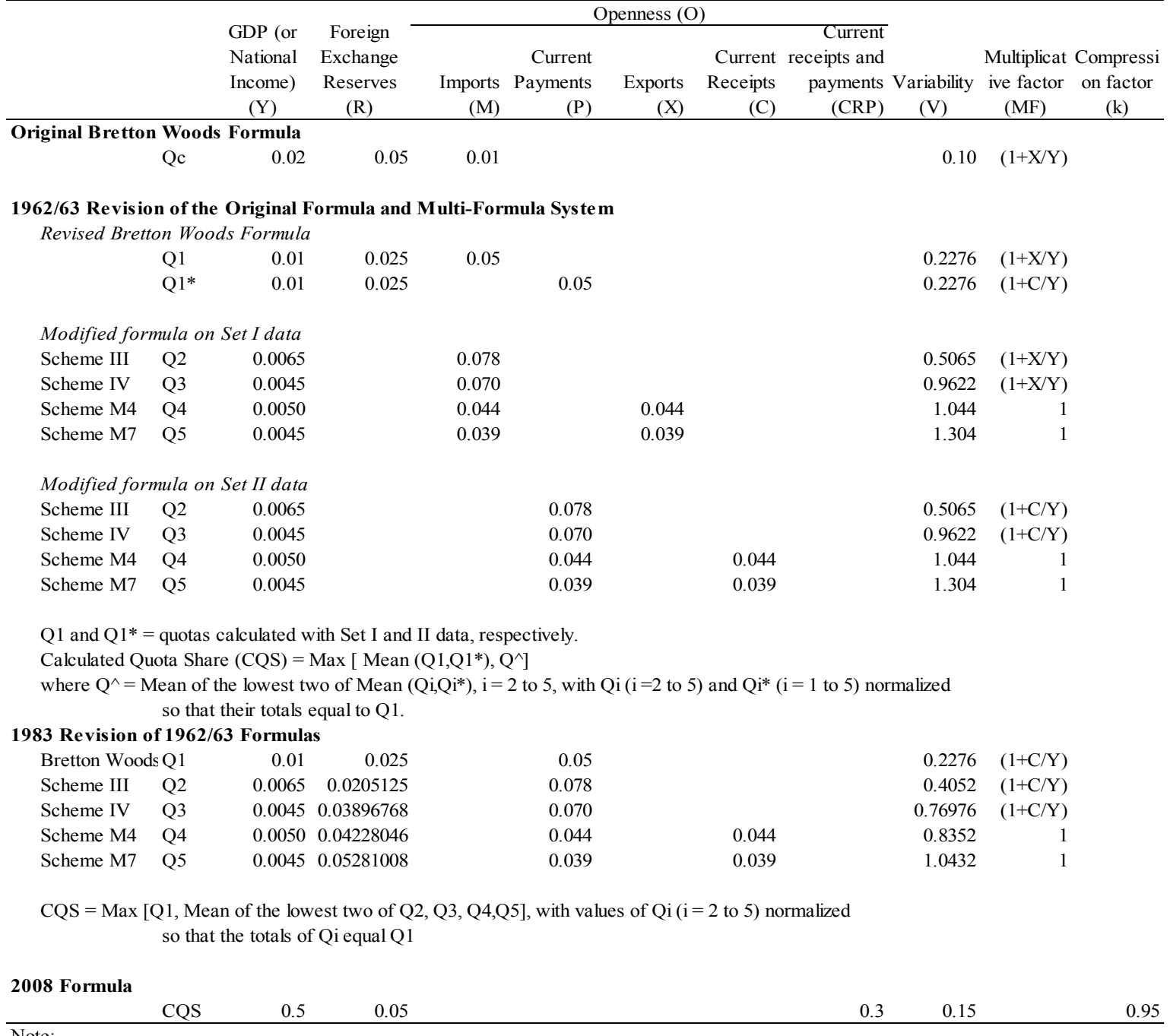

Note:

The formulas prior to 2008 were a variant of : $\left(a^{*} Y+b^{*} R+c * O+d . V\right) *(M F)$. The 2008 formula is: $(a * Y+b * R+c * O+d . V){ }^{n} \cdot$ The parameters a, b, c and d are weights on output $(\mathrm{Y})$, reserves $(\mathrm{R})$, openness $(\mathrm{O})$ and variability $(\mathrm{V})$. MF is a multiplicative factor and $\mathrm{k}$ is a compression factor.

The variables $\mathrm{Y}, \mathrm{R}, \mathrm{O}$ and $\mathrm{V}$ have been defined in the various formulas as follows:

Original Bretton Woods Formula

$\mathrm{Y}=$ National income, 1940; $\mathrm{R}=$ Gold and foreign exchange reserves as of July 1, 1943

$\mathrm{X}$ and $\mathrm{M}=$ Average annual exports and imports, respectively (five-year averages, 1934-38, for both variables)

$\mathrm{V}=$ Maximum fluctuation in exports defined as the difference between the highest and lowest value of exports in 1934-38

1962/63 Revision of the Original Formula and Multi-Formula System

$\mathrm{Y}=$ National income in a recent year; $\mathrm{R}=$ Gold and foreign exchange reserves at the end of a recent year.

$\mathrm{X}$ and $\mathrm{M}=$ Average annual exports and imports, respectively, over a recent five-year period

$\mathrm{C}$ and $\mathrm{P}=$ Average annual current receipts and current payments, respectively, over a recent five-year period

$\mathrm{V}=$ Variability of annual exports (or current receipts), defined as one standard deviation from the centred five-year moving average, from a recent 13-year period. 1983 Revision of 1962/63 Formulas

$\mathrm{Y}=\mathrm{GDP}$ (market exchange rates) in a recent year; $\mathrm{R}=$ Average value of gold, SDRs and foreign exchange reserves in a recent year

$\mathrm{X}$ and $\mathrm{M}=$ Average annual exports and imports, respectively, over a recent five-year period

$\mathrm{C}$ and $\mathrm{P}=$ Average annual current receipts and current payments, respectively, over a recent five-year period

$\mathrm{V}=$ Variability of annual exports (or current receipts), defined as one standard deviation from the centred five-year moving average, from a recent 13-year period. 2008 Formula

$\mathrm{Y}=\mathrm{a}$ blend of GDP converted at market exchange rates and PPP rates (weights of 0.60 and 0.40 , respectively) averaged over a three year period, $\mathrm{CRP}=$ the annual average of the sum of current payments and current receipts (goods, services, income, and transfers) for a five year period

$\mathrm{V}=$ variability of current receipts and net capital flows (measured as the standard deviation from a centered three-year trend over a thirteen year period $\mathrm{R}=$ twelve month average over one year of official reserves (foreign exchange, SDR holdings, reserve position in the Fund, and monetary gold)

Source: IMF (2000) and IMF (2012). 
There was no general increase in the Fund's quotas during the first fifteen years of its existence since the existing magnitude of resources available to it was perceived to be adequate; the first general increase occurred in 1959 and was followed by some modest increases in the 1960s, but these were distributed mostly proportionately to existing quotas. These developments led to a degree of rigidity in members' relative quotas and governance structures in the first couple of decades of the IMF. Thus, countries such as Germany and Japan demanded an increase in their relative quotas during the 1960s and 1970s commensurate with their increased relative weight in the global economy. Reflecting these demands as well as their "position in world trade" and "recent relative economic growth", special increases (shown as 'ad hoc' increases in Table 3) were considered "appropriate and highly desirable" for three countries - Canada, Germany and Japan - during the 1959 increase in the quotas (IMF, 1958). These three countries and another 13 countries were provided further special increases in the fourth quinquennial review in 1965 (Tables 3 and 4).

The fifth general review had a tough balancing act with demands from fast-growing economies for higher quota shares, on the one hand, and the EDEs resisting any further declines in their collective share on the other. A general increase of 25 percent, an ad hoc increase of 10 percent, and the UK accepting a lower order of increase in its quota, facilitated the multiple objectives. During the 1970s and 1980s, oil exporters, benefiting from higher oil prices, also demanded higher quota shares. Non-oil exporting EDEs, however, insisted on protection of their relative shares. Given these demands from the EDEs, the protection of their quota shares became a stated objective of the quota exercise, beginning in the 1970s. At the same time, members from a number of industrial countries also argued that their quota shares should be broadly maintained relative to some other industrial countries. The Fund was unable to sort out these intra-industrial country positions and the issue was escalated to the Group of Ten (G-10) countries for a satisfactory resolution. The negotiations resulted in a decline in the quotas of the 14 industrial economies by 4 percentage points, and a near doubling of the quotas of the major oil-exporters to 10 percent, while protecting the shares of non-oil EDEs.

\section{0s to 1980s: Sixth to Ninth Reviews}

While the overall increase in the quotas was 33.6 percent in the sixth review, the diverse demands from the members - the need to increases shares of some countries and to protect the shares of some others - led to a more ad hoc approach in allocation compared to the previous reviews and indeed the subsequent reviews. These developments then also put a more explicit focus on the quota formula and their variables (de Vries, 1976).

A key binding constraint in the relative distribution of quotas during the 1970s, and later, was the US stance: the US quota share had declined from 33.5 percent in 1946 to around 23 percent by the early 1970s, which took the US voting share to around 21 percent. At that time, a number of important Fund decisions, needed a majority of more than 80 percent of the voting power. Although a special majority of 85 per cent of voting power for certain decisions had been introduced in the First Amendment to the Articles in 1969, 80 per cent majority still applied to some key decisions such as members' acceptance of 
amendments to Articles. Thus, any country with a voting share of over 20 percent could block any of the key decisions. The US voting share at 21 percent continued to provide it a veto power over key Fund decisions, and any reduction in the US voting share below 20 per cent would have led to a loss of its coveted veto power. "U.S. officials argued that the United States needed some margin to retain at least 20 percent of voting power. U.S. officials argued, too, that lowering the voting power of the United States to below 20 percent of the total might well lower the commitment to the Fund by the U.S. government and even by the U.S. public at large, which would be contrary to the interests of the Fund itself" (de Vries, 1985, p.521). This issue was addressed in the Second Amendment to the Articles in 1978, which, inter alia, increased the special voting majority from 80 percent to 85 percent for several decisions. Thus, the US voting share could go down to 15 percent and it could still retain its veto power for certain Fund decisions. A group of leading European countries with their collective quotas being in excess of 15 per cent were also keen to get such veto power. This amended system has till date provided the US authorities the desired flexibility, as their voting share remained consistently above the veto empowering 15 percent.

The seventh review of the quotas (effective 1980) reverted to a general equiproportionate increase, with a selective increase restricted to only 11 EDEs, whose shares were found to be seriously out of alignment with their Calculated Quota Shares (CQSs). Overall, the quotas increased by 51 percent; only 1 percent of the increase was on a selective basis. Both the sixth and the seventh reviews were also characterized by long delays - almost 2 years in each case - between the date when the changes in quotas were approved by the Board of Governors and the date of their effectiveness. Such large lags have meant that the Fund gets the resources it needs to be effective with significant delays, thereby partially defeating the purpose of the quota reforms. The delays have also necessitated reliance on borrowed resources (earlier on the General Arrangements to Borrow (GAB) and now on the New Arrangements to Borrow (NAB)). The lag was less than a year in the preceding two reviews (the fourth and the fifth), but increased to almost 2.5 years in the ninth review. The delay in the current $14^{\text {th }}$ review has taken the lag to a new record of almost 5 years. These lags arise from two procedural factors. First, the quota reforms have been, at times, tied to amendments in articles of agreement, which require 85 percent majority vote for approval. If the ratification of the relevant amendment is held up, the quota reforms also cannot become effective (Table 5). This has been the case with the $14^{\text {th }}$ review (2010 reforms) as well as some of the earlier reviews (for example, the ninth review). 
Table 3: General Reviews of Quotas

\begin{tabular}{|c|c|c|c|c|c|c|}
\hline \multirow[b]{2}{*}{ Review of Quotas } & \multirow{2}{*}{$\begin{array}{r}\text { Board of } \\
\text { Governors' } \\
\text { Adoption of } \\
\text { Resolution }\end{array}$} & \multicolumn{4}{|c|}{ Increase in Quotas (Percent) } & \multirow[b]{2}{*}{ Entry into Effect } \\
\hline & & $\begin{array}{r}\text { Equi-proport- } \\
\text { ional }\end{array}$ & Selective & Ad hoc & Overall $^{1}$ & \\
\hline First Quinquennial & March 8, 1951 & n.a. & n.a. & n.a. & n.a. & n.a. \\
\hline Second Quinquennial & January 19, 1956 & n.a. & n.a. & n.a. & n.a. & n.a. \\
\hline $1958 / 59$ & $\begin{array}{r}\text { February 2, } 1959 \\
\text { April 6, } 1959^{2}\end{array}$ & 50.0 & 0.0 & 10.7 & 60.7 & April 6, 1959 \\
\hline Third Quinquennial & December 16,1960 & n.a. & n.a. & n.a. & n.a. & n.a. \\
\hline Fourth Quinquennial & March 31, 1965 & 25.0 & 0.0 & 5.7 & 30.7 & February 23, 1966 \\
\hline Fifth General & February 9, 1970 & 25.0 & 0.0 & 10.4 & 35.4 & October 30, 1970 \\
\hline Sixth General ${ }^{3}$ & March 22, 1976 & variable & variable & variable & 33.6 & April 1, 1978 \\
\hline Seventh General & December 11, 1978 & 50.0 & 0.0 & 0.9 & 50.9 & November 29, 1980 \\
\hline Eighth General & March 31, 1983 & 19.0 & 28.5 & 0.0 & 47.5 & November 30, 1983 \\
\hline Ninth General & June 28, 1990 & 30.0 & 20.0 & 0.0 & 50.0 & November 11, 1992 \\
\hline Tenth General & January 17, 1995 & & n.a. & n.a. & & \\
\hline Eleventh General & January 30, 1998 & 33.75 & 6.75 & 4.5 & 45.0 & January 22, 1999 \\
\hline Twelfth General & January 30, 2003 & & n.a. & n.a. & n.a. & n.a. \\
\hline Thirteenth General & January 28,2008 & & n.a. & n.a. & n.a. & n.a. \\
\hline 2008 Reform $^{4}$ & & & & 11.5 & 11.5 & March 3, 2011 \\
\hline Fourteenth General & December 15, 2010 & 0.0 & 60.0 & 40.0 & 100.0 & Pending \\
\hline
\end{tabular}

Note: n.a. = not applicable; no increase proposed.

1. Equiproportional increase: Distributed to all members in proportion to existing quota shares. Selective increase: Distributed to all members in proportion to calculated quota shares. Ad hoc increase: Distributed to a subset of countries based on agreed criteria.

2. The February 1959 resolution provided for an equiproportional increase of 50 percent and special increases for three members. The resolution adopted in April 1959 provided for special increases for 14 additional members.

3. The quota shares of the major oil exporters were doubled with the stipulation that the collective share of the developing countries would not fall. Different increases applied to different groups of countries and individual countries' increases within groups varied considerably.

4. The Executive Board approved the 2008 Reforms on April 28, 2008, which provided ad hoc quota increases for 54 countries. The 11.5 percent includes the 2006 ad hoc increases for four countries: China, Korea, Mexico, and Turkey.

Source: IMF Financial Operations, International Monetary Fund (IMF, 2014d). 
Table 4: Agreed Changes in IMF Quotas

(Millions of SDRs)

\begin{tabular}{|c|c|c|c|c|c|c|c|}
\hline \multirow[b]{3}{*}{ Year } & \multirow{3}{*}{$\begin{array}{r}\text { Number of } \\
\text { IMF } \\
\text { Members }\end{array}$} & \multirow{3}{*}{$\begin{array}{r}\text { Proposed } \\
\text { Quotas }\end{array}$} & \multicolumn{5}{|c|}{ Change in Proposed Quotas } \\
\hline & & & \multicolumn{2}{|c|}{ New Members ${ }^{1}$} & \multirow{2}{*}{$\begin{array}{r}\text { General } \\
\text { Review }\end{array}$} & \multirow{2}{*}{$\begin{array}{r}\text { Ad hoc and } \\
\text { Other }\end{array}$} & \multirow[t]{2}{*}{ Total } \\
\hline & & & Number & Quotas & & & \\
\hline $1944^{3}$ & 40 & 7,514 & 40 & 7,514 & 0 & 0 & 0 \\
\hline \multirow[t]{2}{*}{1950} & 49 & 8,037 & 10 & 650 & 0 & $(2)^{4}$ & 523 \\
\hline & & & (1) & $(125)$ & 0 & 0 & 0 \\
\hline \multirow[t]{2}{*}{1955} & 58 & 8,751 & 10 & 837 & 0 & $2^{4}$ & 714 \\
\hline & & & (1) & (125) & 0 & & \\
\hline 1959 & 69 & 14,640 & 11 & 405 & 5,329 & $157^{5}$ & 5,890 \\
\hline \multirow[t]{2}{*}{1965} & 102 & 20,932 & 34 & 757 & 4,792 & 793 & 6,292 \\
\hline & & & (1) & $(50)$ & 0 & - & - \\
\hline 1970 & 116 & 28,776 & 14 & 204 & 7,394 & 246 & 7,844 \\
\hline 1976 & 133 & 38,976 & 17 & 445 & 9,755 & - & 10,200 \\
\hline 1978 & 141 & 59,606 & 8 & 140 & 19,839 & 650 & 20,629 \\
\hline 1983 & 146 & 89,236 & 5 & 394 & 28,177 & 1,060 & 29,631 \\
\hline \multirow[t]{2}{*}{1990} & 154 & 135,215 & 10 & 1,017 & 45,082 & - & 45,978 \\
\hline & & & (2) & (121) & & & \\
\hline \multirow[t]{2}{*}{1998} & $183^{6}$ & 212,029 & 31 & 12,737 & 65,803 & 40 & 76,814 \\
\hline & & & (2) & $(1,765)$ & & & \\
\hline 2001 & 183 & 213,711 & 0 & 0 & 0 & $1,682^{7}$ & 1,682 \\
\hline $2006^{8}$ & 184 & 217,528 & 1 & 8 & 0 & 3,809 & 3,817 \\
\hline $2008^{8}$ & 185 & 238,328 & 1 & 28 & 0 & 20,772 & 20,800 \\
\hline 2010 & 188 & $477,024^{9}$ & 3 & 184 & 238,512 & 0 & 238,696 \\
\hline
\end{tabular}

1. Countries that withdrew from membership or whose memberships were conferred to successor countries are shown in parentheses.

2. As of the dates of adoption of Board of Governors' resolutions proposing adjustments in members' quotas. Total change in proposed quota equals quota increases for new members, plus increases under General Quota Reviews, as well as ad hoc and other increases.

3. Excluding Australia, Haiti, Liberia, New Zealand, and the U.S.S.R., which did not join the IMF at the time of the Bretton Woods Agreement (see Schedule A of the Articles of Agreement), and including increases agreed for Egypt, France, the Islamic Republic of Iran, and Paraguay shortly after the IMF began operations.

4. The quota of Honduras was reduced at its request for 1948 but was restored to the original amount in 1951.

5. Includes SDR 121 million of special allocations for countries with small quotas.

6. Includes the Federal Republic of Yugoslavia, which had not yet succeeded to IMF membership. On December 20, 2000, the Executive Board of the IMF determined that the Federal Republic of Yugoslavia had fulfilled the necessary conditions for membership.

7. Ad hoc increase for China.

8. The Quota and Voice Reform was implemented in two rounds. In 2006, initial ad hoc quotas increases were agreed for four of the most out of line members (China, Korea, Mexico, and Turkey). This was followed by a second round of ad hoc quota increases for 54 members that were agreed to in 2008.

9. The completion of the 2010 reforms is awaiting approval by the membership.

Source: IMF Financial Operations, International Monetary Fund (IMF, 2014d). 
Table 5: General Reviews of Quotas: Implementation Lags, Participation Threshold and US Quota Share

\begin{tabular}{|c|c|c|c|c|c|}
\hline Review of Quotas & $\begin{array}{r}\text { Board of Governors' } \\
\text { Adoption of } \\
\text { Resolution }\end{array}$ & $\begin{array}{r}\text { Lag between the } \\
\text { effective date and the } \\
\text { date approved by the } \\
\text { Board of Governors } \\
\text { (days) }\end{array}$ & $\begin{array}{r}\text { Participation } \\
\text { Thres hold (Percent) }\end{array}$ & $\begin{array}{r}\text { Effectiveness tied to } \\
\text { an amendment in the } \\
\text { Articles of } \\
\text { Agreements? (b) }\end{array}$ & $\begin{array}{r}\text { US Quota Share (end. } \\
\text { Dec) (c) }\end{array}$ \\
\hline First Quinquennial & March 8, 1951 & n.a. & n.a. & & 31.7 \\
\hline Second Quinquennial & January 19, 1956 & n.a. & n.a. & & 29.0 \\
\hline \multirow[t]{2}{*}{$1958 / 59$} & February 2, 1959 & 63 & 75 & & 28.4 \\
\hline & April 6, 1959 & & & & \\
\hline Third Quinquennial & December 16,1960 & n.a. & n.a. & & 27.0 \\
\hline Fourth Quinquennial & March 31, 1965 & 329 & 66.6 & & 25.0 \\
\hline Fifth General & February 9, 1970 & 263 & 0 & & 23.1 \\
\hline Sixth General & March 22, 1976 & 740 & 75 & Yes & 22.5 \\
\hline Seventh General & December 11, 1978 & 719 & 75 & & 21.2 \\
\hline Eighth General & March 31, 1983 & 244 & 70 & & 20.2 \\
\hline Ninth General & June 28,1990 & 867 & $70-85$ (a) & Yes & 19.7 \\
\hline Tenth General & January 17,1995 & n.a. & n.a. & & 18.3 \\
\hline Eleventh General & January 30,1998 & 357 & 85 & & 18.3 \\
\hline Twelfth General & January 30, 2003 & n.a. & n.a. & & 17.5 \\
\hline Thirteenth General & January 28, 2008 & n.a. & n.a. & & 17.1 \\
\hline 2008 Reform & April 28, 2008 & 1039 & & Yes & 17.1 \\
\hline Fourteenth General & $12 / 15 / 2010$ & Pending & 70 & Yes & 17.1 \\
\hline
\end{tabular}

Note:

(a): 85 percent until the end of 1991 and 70 percent thereafter.

(b): Effectiveness tied to an amendment in the Articles of Agreement, which need 85 percent of total voting power.

(c) : US quota share is given for the year preceding the date of Board of Governors' resolution.

n.a. = not applicable.

Source: IMF (2014e); International Financial Statistics, IMF; de Vries (1976, 1985); Boughton (2001, 2012).

Second, the lag also arises due to the participation thresholds that have been incorporated in the quota resolutions. The Fund's Articles require that a resolution involving changes in quotas should be approved by the Board of Governors with 85 percent super majority of the total voting power. This has not encountered difficulty since the US executive can concur to the Board of Governors' resolutions without congressional approval. However, the Board resolutions have also included another requirement - the participation threshold. The new quotas can become effective only if they are ratified by a specified majority of members. Such ratification by a member needs parliamentary or congressional approval in a number of jurisdictions since it involves allocation of budgetary resources for contribution to the IMF quota. This process inevitably takes time because of different countries' budgetary processes and time tables. This participation threshold has been set as a means of pressuring members to respond quickly and, perhaps more importantly, of ensuring that the increases take effect simultaneously and hence avoid temporary shifts in voting power. Though there was no participation threshold stipulated in some reviews, e.g. the fifth review, this threshold has usually been kept quite high - typically 70-75 percent, and as high as 85 percent in two instances at US insistence. It provides an additional controlling lever to the country with the highest quota share, i.e., the US. The effectiveness of the quota increases has indeed been held up then by the delayed ratification by the US: the seventh and the eighth review and the current $14^{\text {th }}$ review. 
The high participation thresholds have also effectively meant that that no increase in quotas during the general reviews become effective without US ratification, although it was possible in principle for some reviews to go ahead without the US approval. The seventh review tested the potential of this decoupling hypothesis. In view of the substantial delay in the ratification of the seventh review by the US, the then Managing Director de Larosiere was "eager to push ahead, with or without the US increase and he directed the staff to make an all-out effort to persuade other countries not to wait. An intense lobbying campaign ensued, and it eventually paid off. On November 28, 1980, with the receipt of an official consent from Tunisia, the Fund had the consent of 127 out of 133 eligible countries, accounting for 75.15 percent of the total. The Executive Board approved an implementing decision the same day, and the increases took effect on November 29" (Boughton, 2001, p. 859). This was possible only because the participation threshold then was less than 85 percent. The United States Congress subsequently consented to the quota increase with alacrity in mid-December 1980. The then Managing Director thus had to apply unusual pressure on the US to obtain its ratification.

The eighth review of quotas led to a further increase of 48 percent in the overall quotas, skewed more towards selective increase (29 percent) than an equi-proportional one (19 percent). The dominance of the selective increase component reflected the recognition, as emphasized by the Managing Director at the start of the discussions in 1981, that the then prevailing quota shares were far out of line with reality and needed a significant adjustment in relative positions. Although the Board of Governors had endorsed this proposal in March 1983, its effectiveness was held up again as it awaited the ratification by the US Congress. The delay in the effectiveness of the quotas (as also in the agreement on an increase in borrowed resources through the GAB mechanism) came at a time when there was an enhanced demand for Fund resources in the aftermath of the Latin American debt crisis of 1982 and other BoP pressures resulting from higher oil prices; these developments on both the supply and the demand side of the Fund's balance sheet led to pressures on the Fund's liquidity position. The Fund's efforts to obtain a temporary loan from the Bank for International Settlements (BIS) to address its liquidity position were also not successful as the dominant members were not in favor of making the IMF reliant on borrowed resources. Given these developments, the then Managing Director de Larosiere once again decided to apply unusual pressure on the US. He instructed IMF staff not to discuss any new lending arrangement with member countries, unless the Fund loans could be financed without the use of borrowed resources. The impasse induced then US President Reagan to publicly endorse the quota and the GAB increase in September $1983^{6}$. Once again such efforts were successful in getting the Congress approval in November 1983 (the IMF quota bill was tied to another bill for investments in domestic public housing projects.).

\footnotetext{
${ }^{6}$ "The IMF is the linchpin of the international financial system. . . . I have an unbreakable commitment to increased funding for the IMF. . . The stakes are great. This [quota increase] legislation is not only crucial to the recovery of America's trading partners abroad and to the stability of the entire international financial system, it is also necessary to a sustained recovery in the United States", President Reagan on September 27, 1983, quoted in Boughton (2001, p. 849).
} 
The ninth review discussions culminated in an agreement in June 1990 for an increase of 50 percent in the overall quotas - unlike the eighth review, the increase was more in the equi-proportional component (30 percent) than in the selective component (20 percent). This outcome partly reflected the initial agreement not to fiddle any more with the formula for this review, although the agreement seems to have been significantly weakened by the subsequent discussions relating to the distribution of quotas among the four major G-7 countries - the UK, Germany, France and Japan (ranked $2^{\text {nd }}, 3^{\text {rd }}, 4^{\text {th }}$ and $5^{\text {th }}$ respectively in the eighth review) - and their inter se hierarchical positions. Japan demanded a higher quota share commensurate with its relative position in the world economy, which would have taken it to the second place after the US. While the UK agreed to a reduction in its quota share and to move to the fourth position, France refused to accept a drop in its rank from the fourth to the fifth place. The IMF Executive Board was unable to resolve this issue of intra-G-7 relative positions and shares, so the issue was reluctantly escalated to the G-7 Ministerial group (just as, the issue was escalated to the G-10 during the fifth review). The Executive Board agreed on the aggregate G-7 quota and tasked the G-7 to distribute the inter se quotas to the seven members (Boughton, 2001). The G-7 then resolved the issue by deciding that Germany and Japan would have equal quotas $\left(6.1\right.$ percent each and tied for the $2^{\text {nd }}$ and the $3^{\text {rd }}$ positions), and France and the UK would also have equal quotas (5.5 percent each and tied for the $4^{\text {th }}$ and the $5^{\text {th }}$ positions $)^{7}$. In the subsequent rounds, Japan moved to the second position, displacing Germany to the $3^{\text {rd }}$ position (Table 6). However, the tie between the UK and France for the $4^{\text {th }}$ and the $5^{\text {th }}$ position continues till date - a quarter century later; their actual quota shares have fallen somewhat further and the CQS share, according to 2013 data update (IMF, 2015b), of the UK is slightly higher than France.

\section{0s to 2000s: Tenth to Fourteenth Reviews}

The eleventh review discussions led to an increase of 45 percent in the overall quotas, with a substantial chunk being distributed equi-proportionally, after there had been no change in the $10^{\text {th }}$ review, completed in 1995. A participation threshold of 70 percent was suggested by the staff and supported by 60 percent majority of the Executive Board; the US, on the other hand, insisted on 85 percent threshold to, inter alia, "help pressure the US Congress to act favorably on the proposal". The Managing Director Camdessus, while indicating his preference for the 70 percent threshold, asked the Board to accept the U.S. request in "a spirit of a consensus. ... There were solid grounds for giving the United States the benefit of the doubt, and for being confident that the United States would not be the last member to agree to its quota increase" (Boughton, 2012, p. 779). Although the quota increase met initial resistance in the US Congress, a confluence of domestic and global financial developments in the autumn of 1998 - the Russian financial meltdown, the near collapse of the Long-Term Capital Management hedge fund, and growing concerns about financial stability in Argentina and Brazil - facilitated the passing of the legislation for the quota increase in the US Congress in October 1998. Other countries, waiting for the United States to act first, began

\footnotetext{
${ }^{7}$ The UK-France bargain also involved an agreement to headquarter the European Bank for Reconstruction and Development (EBRD) in London, with its first presidency going to a French national.
} 
taking their own legislative actions. The 85 percent participation requirement was finally reached, and the quota increases began taking effect in January 1999.

The $12^{\text {th }}$ and the $13^{\text {th }}$ general reviews - completed in January 2003 and January 2008 , respectively - did not lead to any increase in the overall quotas, which then also precluded any change in the relative quota positions, even in an environment of rapid growth in the EDEs. As these reviews coincided with the pinnacle of the Great Moderation era - high and stable growth, low to moderate stable inflation, benign international private capital markets and flows - there was not much appetite for an increase in the Fund's quota resources. In the absence of a broad support among the Executive Directors for an increase in quota resources, the $12^{\text {th }}$ Review was concluded without any increase in the quota resources, but with an understanding that during the $13^{\text {th }}$ Review, the Executive Board would monitor closely and assess the adequacy of IMF resources, consider measures to achieve a distribution of quotas that reflects developments in the world economy, and consider measures to strengthen the governance of the IMF (IMF, 2002, 2003). In the event, the $13^{\text {th }}$ Review, like the $12^{\text {th }}$ Review, did not favor any increase in quota resources.

Meanwhile, there was considerable discussion on quota and voice reforms in the 2006 Singapore Annual Meetings, resulting in an ad hoc increase awarded to 4 most underrepresented countries (China, Korea, Mexico and Turkey). Further, the Executive Board was asked to consider further reform designed to make the Fund governance more reflective of the evolving global economy. The consequent 2008 Quota and Voice Reforms, which required an amendment to the IMF's Articles of Agreement, went into force in 2011. Overall, the quota resources of the Fund were increased by about SDR 20 billion and distributed among 54 countries which resulted in some shift in the representation of dynamic economies. It also enhanced somewhat the voice and participation of low-income countries through an almost tripling of the basic votes of which each member has an equal number. Henceforth, the ratio of basic votes to total votes in the IMF will remain constant, thereby protecting the voice of low income countries. The reform also enabled Executive Directors representing 7 or more members to appoint a second Alternate Executive Director following the 2012 regular elections of Executive Directors.

The 13th review proposal for no increase in quotas was submitted by the Executive Board to the Board of Governors in January 2008, even as the sub-prime crisis had started unraveling in the US in August 2007. The factors which influenced the Board in favor of no increase in the quotas during its deliberations on the $13^{\text {th }}$ review during the course of 2007 were: the steep drop in Fund lending in the preceding years against the backdrop of sustained strong global economic growth and ample access to external market financing for most countries, and the associated increase in Fund liquidity to an all-time high. The Board's judgment against any increase came, even as it stressed the need to continue to closely monitor the adequacy of Fund resources and to stand ready to consider the need for a quota increase in the event that the Fund's liquidity position were to deteriorate. 
Table 6: Countries with the Largest Quotas: Evolution Since Inception

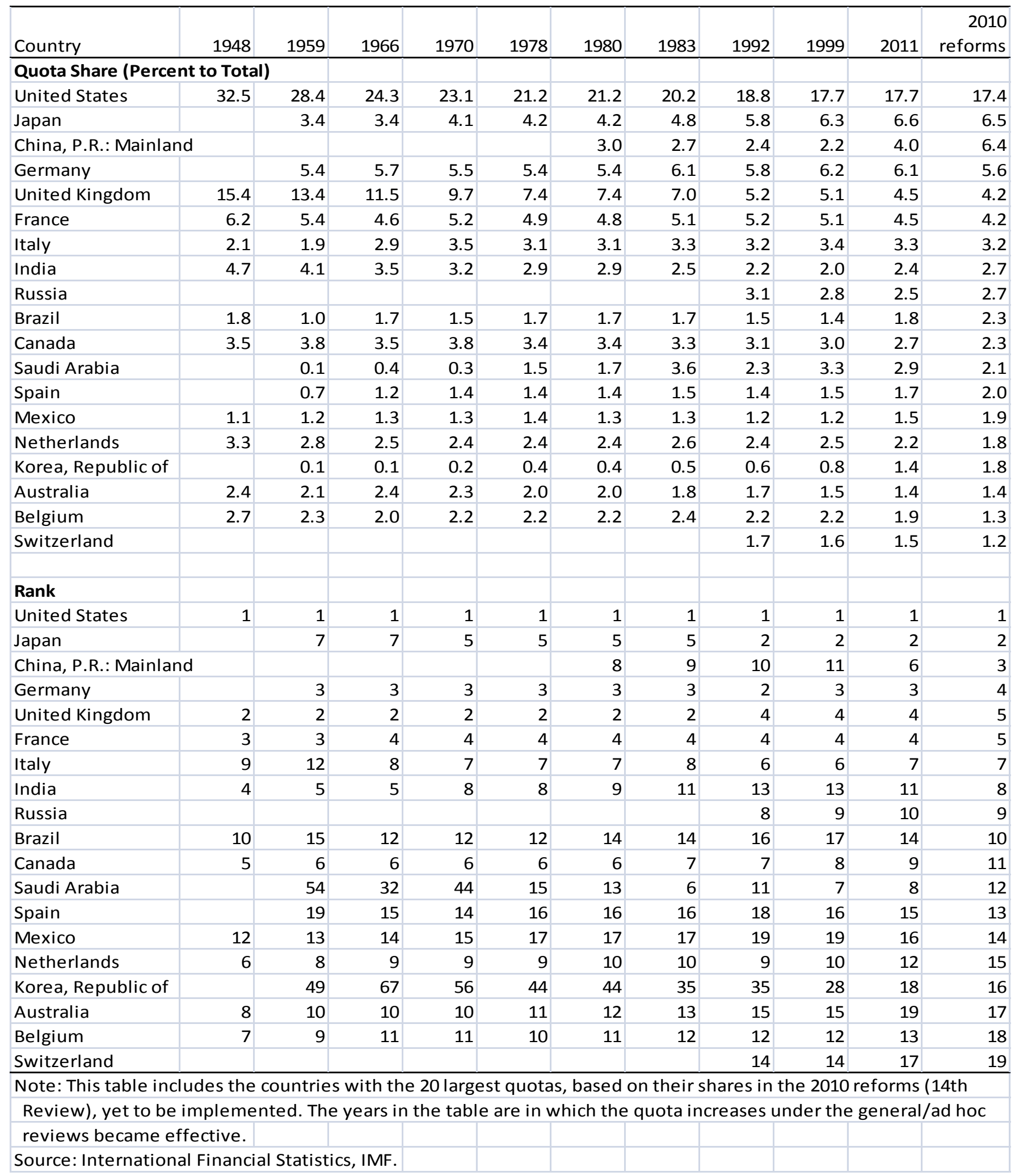


The potential pitfalls of such a backward-looking approach were appropriately flagged by Peter Kenen writing around the same time (Kenen, 2007). In the context of a thenprevalent view that the IMF might have outlived its usefulness, he pointed out that those who take this view note that:

"... many middle-income developing countries have ample access to global financial markets and have accumulated large reserves that allow them to self-insure against any cessation or outright reversal of capital inflows. They also note that there have been no major crises for several years and that large numbers of emerging-market countries have built up large reserves with which they can deal with future crises. One has only to remember, however, how quickly and unexpectedly crises have developed in the past and how they have spread from one country to another. It would thus be imprudent to assume that there will be no crises in the future. On this view, of course, the case for speedy reform of the Fund takes on more strength, not less. It would be far harder to reform the Fund in the midst of a new crisis than to do so now. It is easier to modernize a fire brigade when there are few fires than in the midst of a major conflagration" (Kenen, 2007, p.4).

In the light of the NAFC breaking out in late 2008, Kenen's words proved to be prophetic. It is remarkable that the IMF Executive Board did not perceive a need for an increase in IMF resources as late as 2007-08. This just reflected the complacency that had set in among central banks and financial regulators by the experience of the Great Moderation, buttressed by the ideology of light touch regulation. There was little appreciation of the ongoing asset price boom, global financial imbalances, and broad based financial excesses that were about to lead to the Great Recession.

In this context, the observations of the Executive Board as far back as 1958 in its report to the Board of Governors - when capital accounts were almost closed, whereas today they are increasingly open and highly interconnected - are highly apposite:

"The Fund has two main tasks which are clearly intertwined. It promotes international monetary cooperation and exchange stability as a basis for the balanced growth of world trade. It also provides financial assistance to members to help them stabilize their currencies, maintain or move toward convertibility, and overcome temporary balance of payments problems without resort to policies that would be harmful to national or international prosperity. While the first task is a continuing one, experience has shown that the granting of financial assistance tends to be concentrated in certain periods characterized by exceptional strains in the world's monetary system. Major economic and financial developments will often affect several countries more or less at the same time, so that the calls on the Fund's resources may be of substantial proportions in a relatively short period...... The only conclusion can be that the Fund must remain prepared for diverse contingencies, many of which cannot be clearly defined in advance. .... [T] concerned with only the present or the immediate future; its members must be 
assured that it is adequately equipped to meet the strains which may arise in emergencies or other adverse circumstances" (IMF, 1958).

Kenen's (2007) arguments for a continued role for the Fund were and are based on a view that, in the modern world, only the EDEs are prone to financial crises and hence the Fund's continued relevance is in the context of likely demand from such countries. As the subsequent events indicated, not only the EDEs but also the AEs are equally, if not more, susceptible to crisis and, as and when a crisis occurs, their demands for Fund resources would be even higher, given their greater financial openness and inter-connectedness. From the perspective of this paper, however, the more important point is Kenen's key message that we should be prepared for financial crises in future, even though there might be long periods of tranquility in between.

This is visible in the cycles of the Fund's actual lending pattern since the 1950s. A few important features of these trends are: First, during the 1950s, the 1960s and the 1970s, the AEs were rather regular users of Fund's lending support (Chart 4). Almost 40 percent of the Fund's loans were to the AEs during these three decades. Over the next three decades, the AEs' recourse to the IMF lending facilities fell sharply, and the EDEs turned out to be the predominant borrowers. Perhaps, this pattern led to the view that the Fund's usefulness can be only for the EDEs.

The 2008 NAFC has, however, led to a situation where the AEs are now the predominant borrowers, with a share of almost three-fourths in total lending. Here, it is also worth noting that the AEs share of three-fourths in the total lending is despite the fact that these economies have relied heavily on even greater financial support from non-IMF resources. Under the troika arrangement, the IMF support to the Euro zone countries has been around a third or less of the total support availed by these countries. Second, countrywise analysis indicates a growing intensity in the use of Fund's resources: the number of countries with outstanding Fund credit in excess of 600 percent of their own quota was at its highest in the post-NAFC period. The maximum ratio for any country also shows an uptrend: this ratio was less than 100 percent in the 1950s and the $1960 \mathrm{~s}$, and jumped to around 500 percent during the 1970s and the 1980s (Chart 5). With the advent of capital and financial account crises, this ratio ballooned to 1500 percent plus in the Asian financial crisis (Korea in 1998), then to 1700 percent for Turkey in 2002-03 and finally to $1800-2300$ percent during the euro area sovereign debt crisis (led by Portugal and Greece).

The absence of the quota increases during the $12^{\text {th }}$ and the $13^{\text {th }}$ reviews on the one hand and the continued rapid growth in the EDEs relative to the AEs had led to increasing realization of the EDEs quota shares being significantly out of line with their economic weight and questions over the Fund's governance structure (Table 1). This was addressed partially through two rounds of ad hoc increases agreed in 2006 and 2008 to 54 countries.

This process gathered some pace during the $14^{\text {th }}$ Review, which agreed on an increase of 100 percent in total quota resources, as a consequence of the NAFC - the largest increase in the general reviews ever, although coming after a gap of almost 13 years. However, the increase in the Fund's quota resources has either stagnated or declined relative to global economic activity (Charts 6-8), even as there has been significant increase in gross capital 
inflows and outflows, along with the expansion in trade volumes. A notable feature of the $14^{\text {th }}$ review was that the whole of the increase was either selective or ad hoc (i.e., no equiproportional increase), in order to address more effectively the relative quota shares. Although the $14^{\text {th }}$ review realignment was a step in the right direction, it did not go far enough, and the impact has been exacerbated by the delays in its ratification.

Despite the universally accepted need for reform of IMF quotas and governance, which has gathered force since the 2006 Singapore Annual Meeting of the IMF, and the 2008 reforms, the $14^{\text {th }}$ review, approved in 2010 has not come into force because of the inability of the US Administration to obtain approval from the US Congress. Since this review was tied with an amendment to the Articles of Agreement on governance, the threshold for coming into force of the quotas is effectively 85 percent, thereby giving the US veto power over the reform. There were three effectiveness conditions for this review: (i) consent by members representing 70 percent of the quotas; (ii) Entry into force of the 2008 Voice and Participation Amendment; and (iii) Entry into force of the Board Reform Amendment. The first two conditions have been met. It is the third condition that has been held up because of the US stalemate.

There has been no lack of commitment expressed by the US Administration. More than three decades after President Reagan did, the current US administration has also argued that the IMF reforms are good not only for the global economy but also for the US; these efforts have not succeeded so far though ${ }^{8}$. The current 5 year delay in ratification of the $14^{\text {th }}$ Review is unprecedented in the IMF's 70 year history, and the global economy continues to suffer from significant fragility and volatility resulting from the 2008 North Atlantic Financial Crisis. It would therefore seem self evident that IMF's full membership, the G20 and IMF's management, should have all applied unusual pressure on the United States to complete the IMF quota increase and 2010 reform, notwithstanding regular calls on the US to ratify the reforms ${ }^{9}$.

\footnotetext{
${ }^{8}$ US Treasury Secretary Jack Lew noted in March 2015: "A well-resourced and effective IMF is indispensable to achieving our economic and national security interests, protecting the health of the U.S. economy, and enhancing the prosperity of America's workers. As the largest shareholder in the IMF and the only country with veto power over major IMF decisions, we have a great deal of influence within this critical institution. The proposed reforms will put the IMF's finances on more stable footing over the long-term, help modernize the IMF's governance structure, and preserve America's strong leadership role in shaping the institution. .... Our continued failure to approve the IMF quota and governance reforms is causing other countries, including some of our allies, to question our commitment to the IMF and other multilateral institutions that we worked to create and that advance important U.S. and global economic and security interests. Our international credibility and influence are being threatened" (Lew, 2015).

${ }^{9}$ For example, the G-20 Finance Ministers' communiqué of September 2015 (G20, 2015) noted: "We remain deeply disappointed with the continued delay in progressing the 2010 IMF Quota and Governance Reforms. We reaffirm that their earliest implementation is essential for the credibility, legitimacy and effectiveness of the Fund and remains our highest priority. We strongly urge the United States to ratify the 2010 reforms as soon as possible. We reaffirm our commitment to maintaining a strong, well-resourced and quota-based IMF". The IMF Managing Director, on the conclusion of this G-20 meeting, noted: "I fully share the G20's deep disappointment with the continued delay in achieving the IMF's 2010 Quota and Governance reforms. I continue to strongly urge the ratification of these reforms as soon as possible" (Lagarde, 2015).
} 


\section{Chart 4: Use of Fund Credit: Major Country Groups}

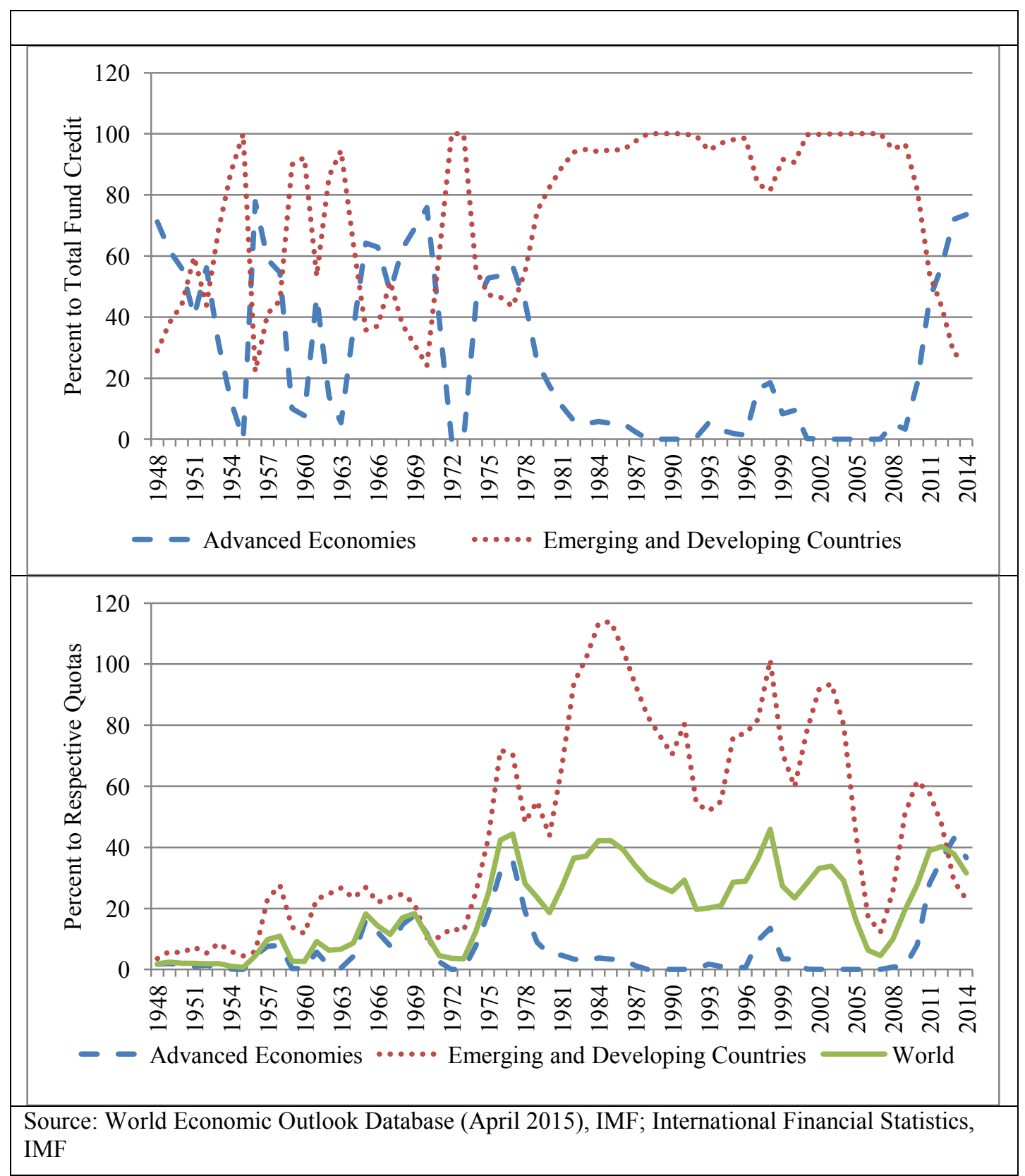




\section{Chart 5: Use of Fund Credit: Country-wise}
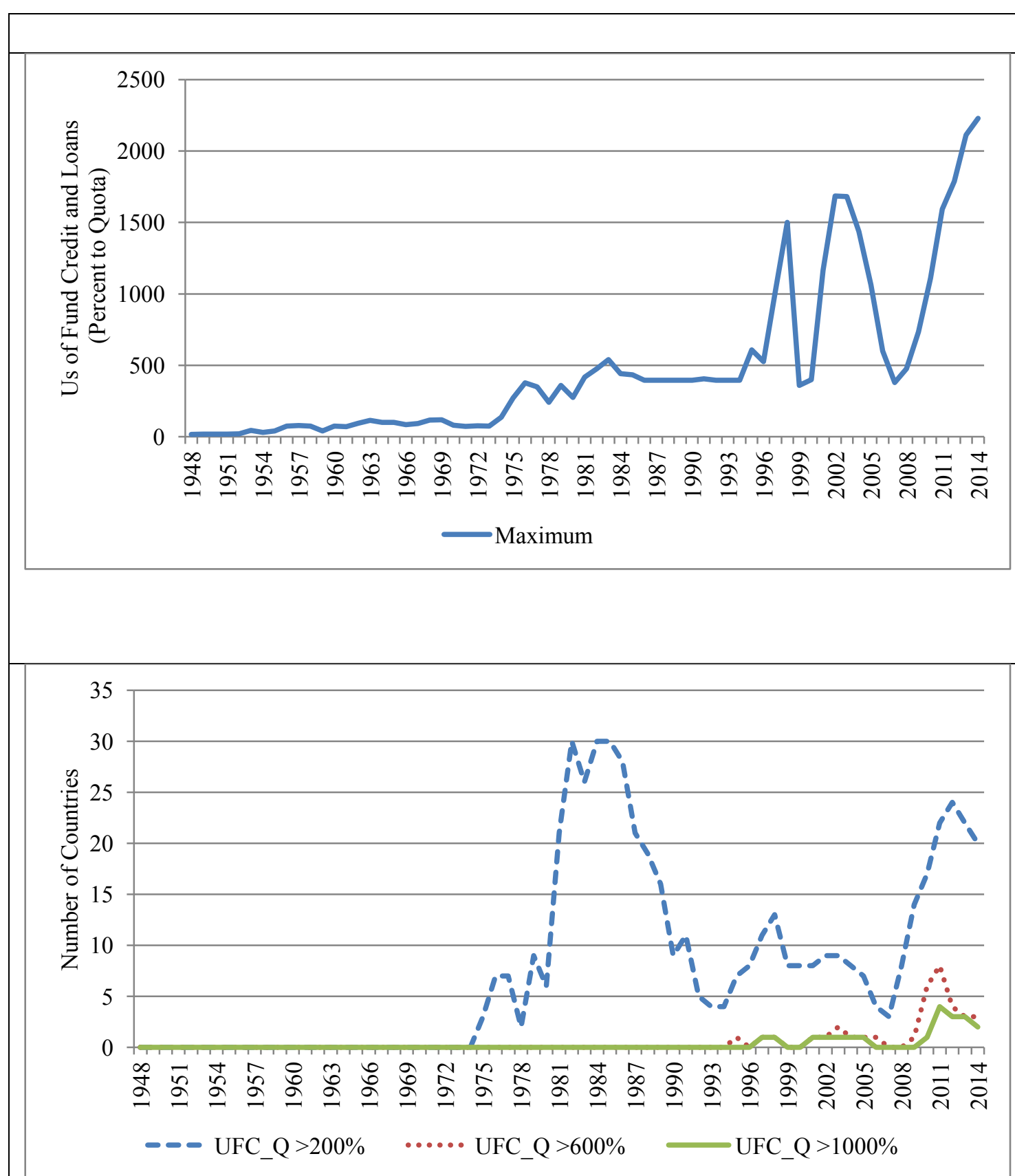

Note: UFC_Q = Use of fund credit and loans (percent to quotas).

Source: International Financial Statistics, IMF. 


\section{Chart 6: IMF Total Quota Resources}

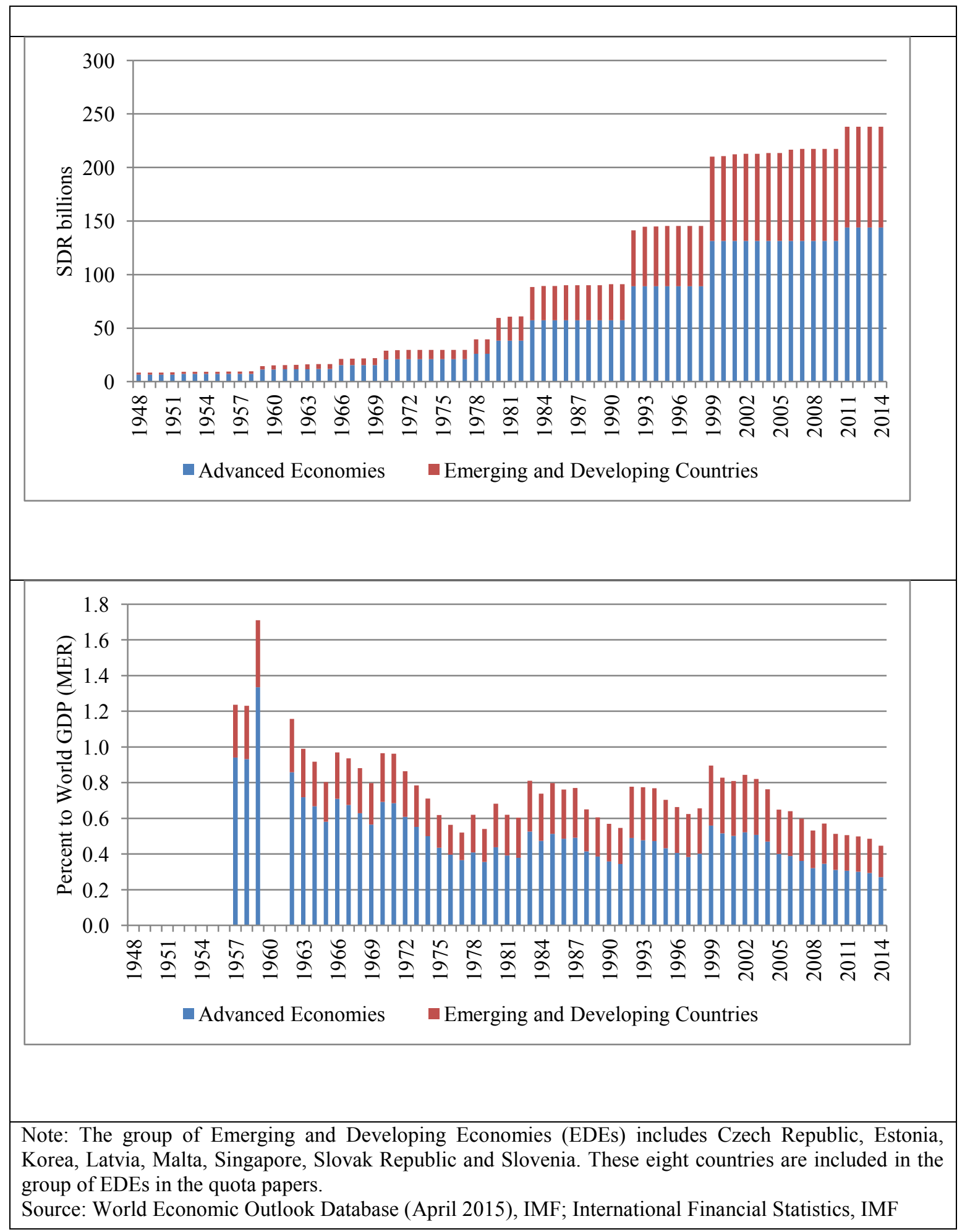




\section{Chart 7: IMF Quota Resources and GDP}
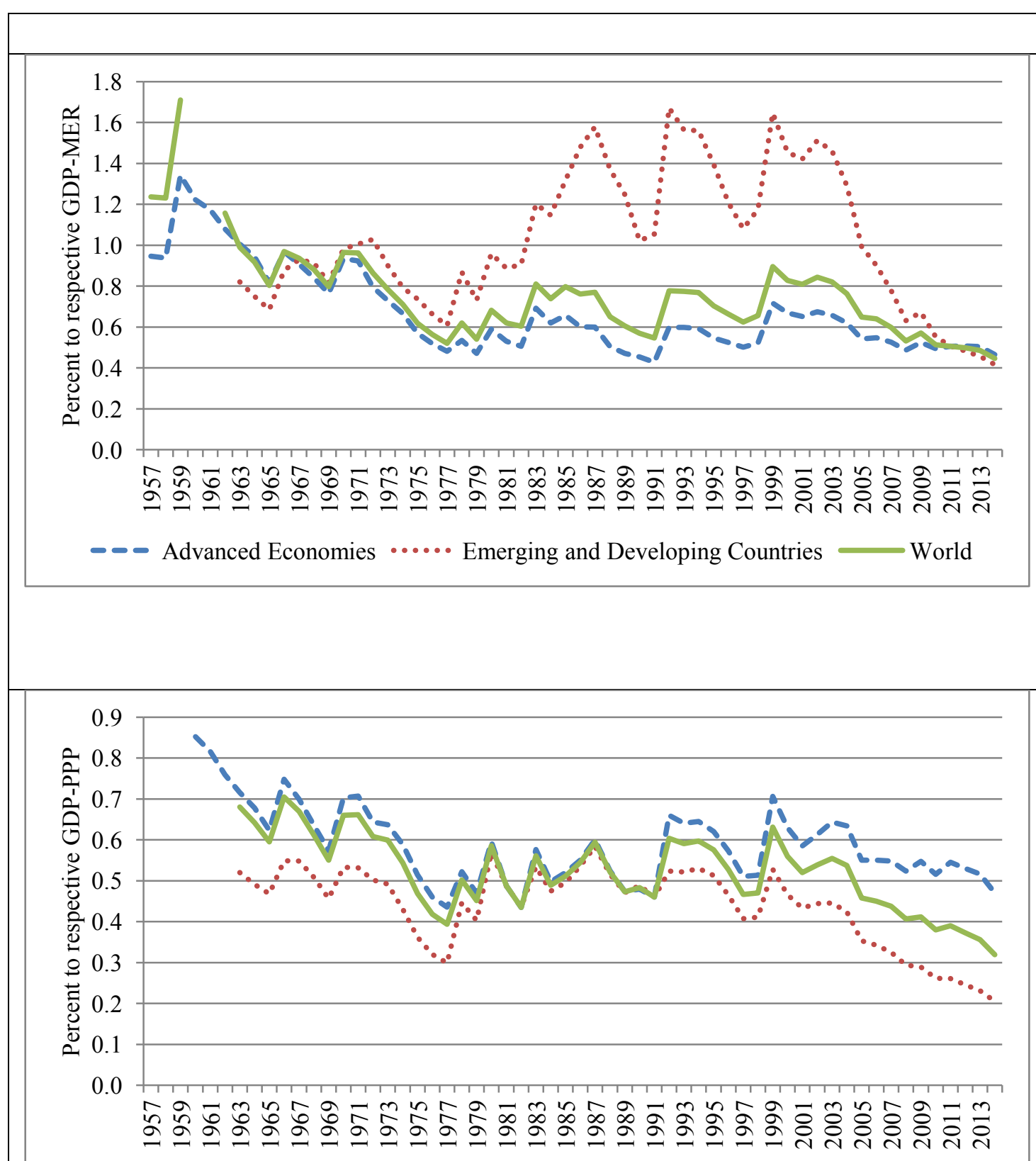

- Advanced Economies ….. Emerging and Developing Countries $\longrightarrow$ World

Note: Quotas of advanced economies, emerging and developing countries and world are scaled with respect to their respective GDP aggregates. While the top panel chart is with respect to GDP at market exchange rates (MER), the bottom panel is with respect to GDP at purchasing power parity (PPP) basis. Source: World Economic Outlook Database (April 2015), IMF; International Financial Statistics, IMF 


\section{Chart 8: IMF Total Quota Resources and Trade in Goods and Services}

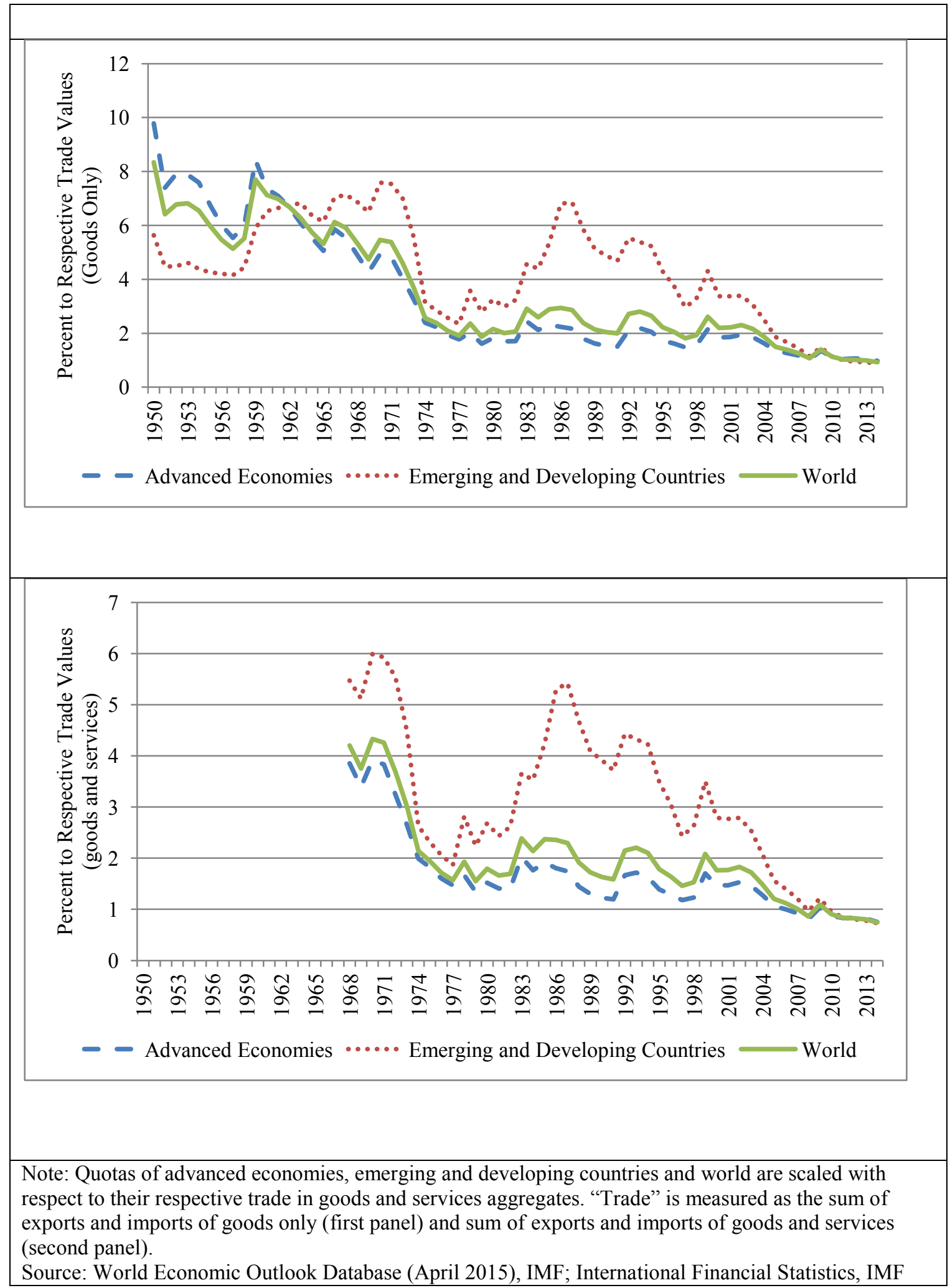


The current complacency is perhaps due to the availability of comfortable liquidity in the form of the NAB and Bilateral Borrowing Arrangements, which can potentially provide more than twice the IMF's quota resources if necessary; and ratification delays also postpone the agreed reduction in quota shares of some important members. Unlike the early 1980s, when the membership was not in favour of excessive reliance on borrowed resources, and hence pressed the United States to ratify the $8^{\text {th }}$ review, similar discomfort with borrowed resources is not in evidence today. It has also been argued that the Seventh and Eighth quota reviews needed a participation rate of 70 percent, effectively giving the US no veto over the effectiveness of the quotas and hence the management's pressure tactics were successful during these two reviews. With the 85 percent threshold having been stipulated for the $14^{\text {th }}$ review, such leverage is not available today. But, it is debatable as to whether the 1980s style tactics would in fact have been ineffective today. Relative to the 1980s, the global economy is much more integrated today, through both the trade and financial channels. In such an environment it can be argued that spillbacks to the US economy from a potential decision to freeze new IMF lending could perhaps motivate the US for an early ratification of the 2010 reforms and to assume its traditional role in global economic governance. The potential role of spillbacks on the US economy is also evident from the continued push back to the date of the Federal Reserve's first rate hike.

The 2011 NAB and the 2012 Bilateral Borrowing Agreements were reached in recognition of the severity of the NAFC. The generous contributions of the membership demonstrate the importance attached by them to the need for an adequately resourced IMF to tackle potential crises. These arrangements were expected to be temporary arrangements pending the effectiveness of the $14^{\text {th }}$ review. In retrospect, they may have had a deleterious effect on the urgency of US Congressional approval since the IMF can be seen to be adequately resourced as long as these arrangements exist. The continued activation of NAB and renewals of the Bilateral Borrowing Arrangements, with potential financing more than the 2010 quota resources, arguably reduced the urgency of the 2010 quota reforms. Thus, as the current validity of these arrangements expires in 2016-17, and assuming the 2010 reforms are still not ratified, new opportunities may arise for the IMF membership and management to apply unusual pressure on the US with the objective of returning the IMF to its traditional structure of being a quota based institution. This is important since the EDE creditor members, who contribute to both the NAB and the bilateral arrangements, do not receive a commensurate voice in the Fund.

In any case even when the $14^{\text {th }}$ review or the 2010 reforms become effective, they would increase the quota share of the EDEs marginally from 39.6 per cent to 42.4 per cent. This would still leave their share well below their share in the global economy of almost 60 per cent in PPP terms. The importance of the $14^{\text {th }}$ review therefore is as much related to the doubling of overall quota resources as it is to voice and representation reforms, which will need to be continued in the usual 5 year cycles.

Under the Fund's articles, the $15^{\text {th }}$ review of quotas is required to be completed by December 2015, but the deliberations on this crucial issue have yet to be started in the Fund's Executive Board. Thus, we see a widening chasm between the EDEs relative weight in the global economy and their say in the global economic governance: from 7.6 percentage points in 2000 to almost 21 percentage points now. Given the backward-looking nature of the quota 
adjustments, the lags in the implementation and some serious flaws in the existing quota formula, the gap between the economic weight of the EDEs and their voice in the global governance can be expected to persist under the current approach.

Longer-term projections from the Organization for Economic Cooperation and Development (OECD) indicate further accentuation of these trends in favor of the EDEs ${ }^{10}$ (Chart 9). The share of the G7 in global GDP now exceeds the BRICS by 12 percentage points; given the continued rapid growth in the BRICS vis-à-vis the G7, the OECD (2014) projections indicate a reversal of this position by 2025, when the BRICS share in global GDP would exceed that of the G7. By 2060, the OECD projects that the BRICS share in global GDP could increase to 49 percent, whereas that of the G7 would fall to 30 percent. Turning to individual countries, China's share in global GDP would exceed that of the US in 2021 and by 2060, the Chinese GDP would be eight percentage points higher than that of the US (25 percent vis-à-vis 17 percent). Also, by 2060, the Indian share in global GDP (18 percent) would be higher than that of the US (17 percent). If these projections turn out to be correct, the global economic structure would be starkly different from today and the governance at the global economic institutions needs to reflect this structural shift. Of course, such longterm projections are subject to a lot of uncertainty and the high past growth need not necessarily continue in the future ${ }^{11}$.

\section{NEED FOR REVISION OF THE QUOTA FORMULA}

The way forward is clear and well known: a significant realignment of quota shares in favor of the EDEs through a transparent quota formula, with conceptually sound variables. First, there is wide agreement that the formula should have a larger weight on GDP. The 2008 formula made a welcome move to include PPP GDP in the formula, with weights of 60 percent for GDP at MER and 40 percent at PPP. In the past, there have been questions over the quality of the PPP GDP data, but the Fund staff has clearly shown that these data are of high quality and are as good as the underlying GDP data and also that the quality of PPP data is broadly comparable to other data used in the quota formula (IMF, 2014a, 2014b, and 2015b). Also, the PPP GDP favors low income countries. GDP at PPP thus helps in increasing the weight of low income countries, which would enhance their voice in governance. These findings make a stronger case for a significant increase in the weight on PPP GDP.

\footnotetext{
${ }^{10}$ These data are based on the OECD (2014) and differ somewhat from that of the IMF (2015a).

${ }^{11}$ As Pritchett and Summers (2014) argue, abnormally rapid growth is rarely persistent; regression to the mean is empirically the most salient feature of economic growth. In developing countries, episodes of rapid growth are frequently punctuated by discontinuous drop-offs in growth and accordingly, these authors expect that growth in China and India will be much less rapid than is currently anticipated. We are, for example, witnessing a marked slowdown in EDE growth at the present time, including the BRICS countries
} 
Chart 9: Projected Structure of the Global Economy (2014-2060)
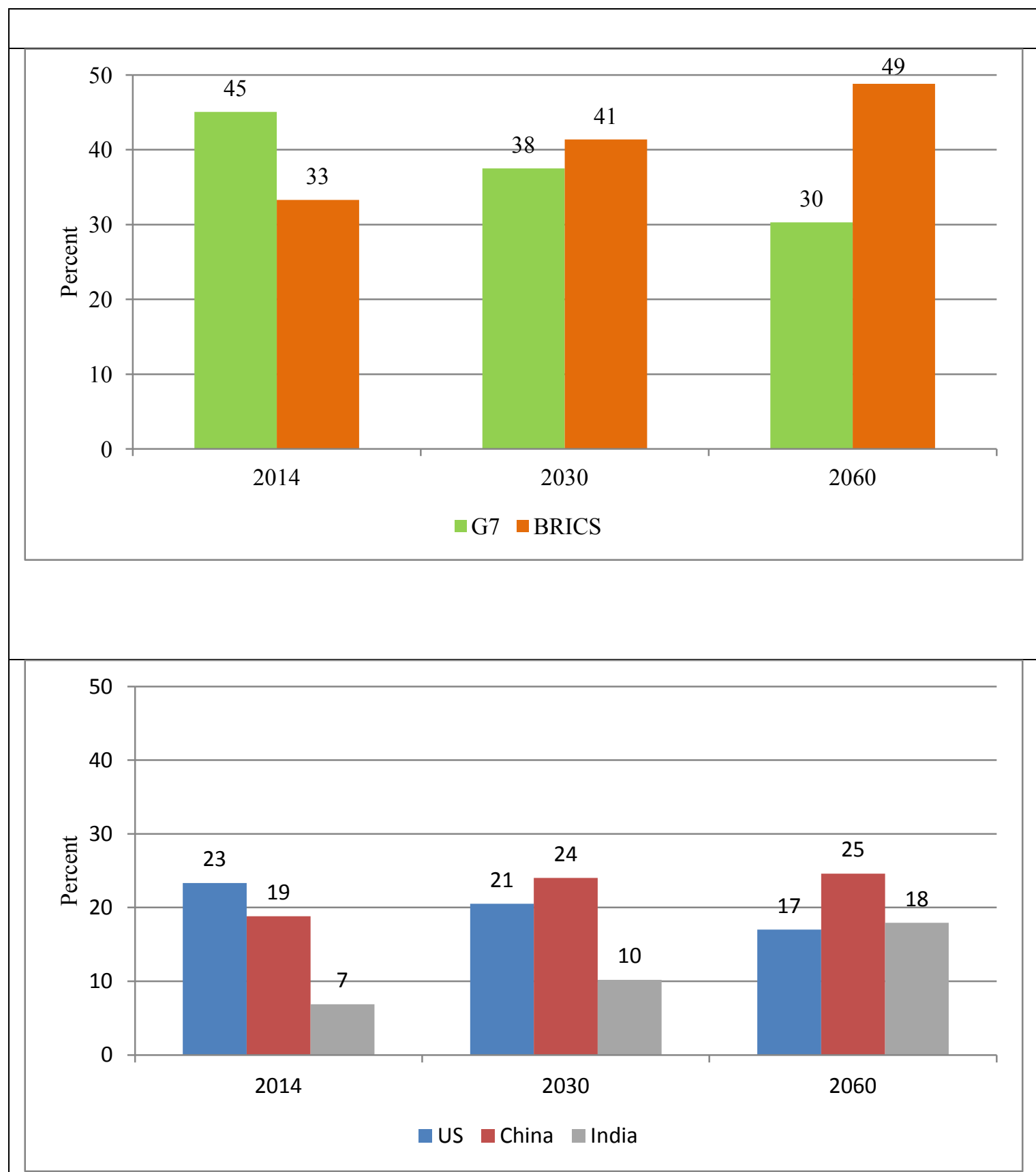

Source: Economic Outlook No. 95 - Long-term Baseline Projections Dataset, Organization for Economic Cooperation and Development (OECD) (May 2014). 
A key weakness of the current formula is the large weight it places on openness, a conceptually flawed variable. The openness variable, as currently measured, is inversely related to GDP and size. Indeed, if we take two economies, one large and one small, but equally open in terms of their trade and other external sector policies, the current quota formula gives an outsized and undue benefit to a country smaller in size. Openness, as currently measured, has no relation to a country's interconnectedness in the global economic and financial system. This is well illustrated with a few examples: according to data in IMF (2014c), the US is the sixth most closed economy (as measured by openness/GDP ratio) in the world, even more closed than Iran, Sudan and the Central African Republic! The openness variable is also biased towards countries in monetary and currency unions such as those in the euro area. The role of openness in the formula, thus, needs to be minimized significantly, if not eliminated fully: this weight ought to be shifted fully in favor of the GDP-blend.

The third variable in the formula is variability of current receipts and payments. In this context, the Fund staff has documented: (i) a weak relationship between variability and balance of payments needs, (ii) almost all countries in the bottom quartile of the income distribution benefit from a higher weight on PPP GDP relative to market GDP and they also record the largest relative gains. Moreover, size does not appear to be strongly related to the benefits of a higher share of PPP GDP, while gains from openness are positively related to income (IMF, 2014a, 2014b, and 2015b). Given these findings, dropping the 'variability' variable and shifting the weight towards PPP-GDP would be helpful to the LICs.

A greater shift of weight to the GDP variable will also be of benefit to the United States, whose calculated quota share, under the current formula, would otherwise fall below the veto controlling threshold of 15 per cent in the next Review. This issue can be expected to gain in importance again, in view of the rapid relative growth of the EDEs and the expected decline in the US' quota and voting shares: the calculated quota share (CQS) of the US, based on the 2008 quota formula, has declined from 19.0 percent in 2005 to 14.5 percent in 2013, according to the latest staff update (Table 1, p.6, IMF, 2015b). The CQS of 14.5 percent would indicate an even lower voting share - well-below the veto controlling share of 15 percent. It remains to be seen as to how this issue is addressed in the next few years: whether there would be a further amendment to the articles to increase the super majority voting percentages, or whether the quota formula would be changed, or whether the US would be willing to let go its veto power? There is also a respectable view that a reduction in the US voting share below 15 percent is a non-starter, until the European Union chairs agree to a substantial reduction in their combined voting share to something close to the US share from their current share of 30 percent of (Truman, 2008), Finally, the current quota formula by design is lagged, and impact of these lags is exacerbated by implementation delays. For example, the GDP variable in the formula is based on three-year averages. The $14^{\text {th }}$ review, agreed to in 2010, used data available up to 2008. For the GDP variable, given the averaging practice, the data actually used was an average of 2006, 2007 and 2008. The share of the 'EDEs plus 8' in the global GDP (PPP) was 50.9 percent in 2006, 53.6 percent in 2008, 56.2 percent in 2010 and almost 60 percent in 2015 - an increase of almost 9 percentage points in just a decade. In an environment of persistent structural excess growth in the EDEs vis-à-vis the AEs, the current quota formula is quite backward looking. This issue can be addressed 
through a host of options, for example, (a) by shifting either to the GDP data for the latest year (rather than averaging the latest three years) or, (b) by taking a weighted average of the latest three years, with substantially more weight to the latest year and reduced weights to the preceding two years, or (c) by moving towards a 2-year average, with greater weight for the latest year. As it is, there is considerable hysteresis in the evolution of voice in the Fund, since the formula effectively only applies to the distribution of additional quota resources. Changes in weight can also take place through ad hoc allocations as has often been done. There is no provision at present for reduction in any absolute quotas of any member. It can be argued that such hysteresis has its own value in providing some stability to the structure of the Fund's governance.

It is remarkable that, in view of the stalemate related to the $14^{\text {th }}$ Review, there has been effectively no general increase in the IMF quota resources since 1998, apart from the selective small ad hoc increases of 2006 and 2008. This period has been marked by both a massive expansion of the global economy between 1998 and 2008 and the ensuing Great Recession, along with a substantial increase in the volume as well as volatility of cross border capital flows. Moreover, as a consequence of the NAFC, the size of programs in relation to quotas or respective GDPs has also been on the ascendant. Consequently, one would have thought that global leaders would have given much greater priority to the increase in the IMF's permanent quota resources. Instead, a degree of comfort has been achieved by an unprecedented resort to borrowed resources through the New Arrangements to Borrow (NAB) (SDR 370 billion) and potential resources through the Bilateral Agreements (SDR 270 billion). The NAB borrowings were envisaged to be temporary, but have acquired a more durable character.

These developments have implications for the credibility and legitimacy of the Fund. For the Fund to perform its functions, it must be adequately resourced, it must be seen as credible and effective, and its governance structure must be beyond reproach.

\section{Emerging Powers and Global Economic Governance: Their Role in GOVERNANCE IN DIFFERENT GROUPS}

A peculiar feature of IMF's governance over the years has been the role of informal groups outside the Fund. It is reported that in the late 1940s to mid-1950s, there was a practice of "informal meetings at a senior level by US officials with a handful of European counterparts..........The practice of discussing matters within the IMF's mandate in informal groups led to situation where important decisions were effectively taken in the outside groups" (Mountford, 2008, p.8). This practice got semi-formalized in the 1960s with formation of the Group of Ten (G-10 - US, U.K., Germany, France, Italy, Japan, Canada, Belgium, Netherlands, Sweden, Switzerland). The G-10 was formed originally to create the GAB whereby this group of countries agreed to supplement IMF resources through borrowings in the event that one of the group members needed substantial amounts from the Fund and existing resources were found to be inadequate. It did have to be invoked several times in the 1960s to fund countries like France, U.K. and Italy. Discussions in the G-10 
were effective in leading to the creation of the SDR in 1969, and the December 1971 Smithsonian Agreement following the collapse of the Bretton Woods System.

The dominance of North America and Western Europe in the governance of the IMF is well illustrated by the importance of G-10 in key IMF decisions at various times, particularly in the 1960s and 1970s. This led to some concerns among the excluded members that a "new ideology of cooperation among industrial countries was replacing the universal aspirations of Bretton Woods. They were also upset that the GAB was set up in such a way that there was a "double lock" on IMF resources, namely that, in addition to a decision by the Executive Board, the G-10 would decide (at the Ministerial level) on any Fund standby arrangement that included GAB financing" (Mountford, 2008). One of the consequences of such concerns was the formation of groups by developing countries such as the G-77 in the United Nations and the G-24 in the IMF/World Bank. But these groups have not been particularly influential in IMF governance.

As the Bretton Woods system broke down, discussions arose on the need for a more comprehensive reform of the international monetary system. These discussions led to the formation of the "Committee of Twenty" in 1972, by the IMF's Board of Governors formally called the "Committee on Reform of the International Monetary System". This brought IMF governance and reform issues back into the IMF. The Committee was fully representative of the IMF membership, in the same manner as in the IMF Executive Board. This was somewhat curious since the Executive Board already existed! It was perhaps felt that decisions regarding the future of the international monetary system needed to be taken at a higher decision making level. So, the C-20 consisted of the Minister, Central Bank Governor and Executive Director of each constituency. The main contribution of the C-20 was the adoption of the Second Amendment to the IMF Articles of Agreement, which effectively:

i. Legalized floating exchange rates: the definitive move away from the now defunct Bretton Woods system;

ii. Increased tremendously the number of decisions requiring super majority from 18 after the First Amendment in 1969 to 39 additional types of decisions; and

iii. Allowed for the formation of a decision making "Council" at the Ministerial level, between the Executive Board and the Board of Governors.

The latter recommendation was never put into effect though the Articles were indeed amended to enable the formation of such a Council. There was, perhaps, some pushback from the Executive Board since such a decision making Council could have detracted from its own decision making functions.

Instead, the "Interim Committee" was formed in 1976 as an advisory body at the ministerial level in a manner very similar to the erstwhile C-20. It was called "Interim" since it was intended to be temporary until the proposed Council was formed, which has not happened to date. The Interim Committee functioned till 1999, when it was renamed as the International Monetary and Financial Committee (IMFC), indicating some degree of permanency. Both the IC and IMFC, though being advisory in nature, have essentially functioned as the top most deliberative body in the Fund's governance. Right through their existence, they have met twice a year, and the Fund's key decisions have been intermediated through them before formal adoption by the Executive Board or the Board of Governors. 
Although the IC and IMFC was representative of the IMF's full membership, the domination of industrial countries in IMF's governance was also a feature of their functioning. Until 2008, their chairmanship was restricted to Finance Ministers from industrial countries. It is only since then that an informal policy of 3 years rotation has finally been adopted with the Chairman to be successively elected from the 5 regions as currently delineated by the Fund. Thus, until 2008, all the Chairmen of the IMFC were European or Canadian, while the Managing Director has, of course, always been European.

\section{The Executive Board}

The re-allocations in relative quotas have also led to some change in the representation at the Executive Board. In the initial years of the IMF's setting-up, China, and India were among those with the five largest quotas and thus were entitled to "appoint" their own Directors ${ }^{12}$. Half of the original 12 Executive Directors came from non-industrial countries, although their share in the voting power was less than a third (31 percent) (Boughton, 2001). Given its sluggish growth, India lost its 'appointed' position status in the Executive Board in 1970 following the quota changes in the fifth general review, although the change was implemented in November $1972^{13}$. India was able to retain its seat in the Executive Board, although its status shifted from an 'appointed' chair to an 'elected' chair's .

India's appointed seat was taken by Japan, given its increased quota on the back of its strong growth performance. Japan had joined the Fund in 1952 with the eighth largest quota, moved to the fifth position in 1970 and gradually to the second position in 1992 (Table 5). Amongst other major countries, Germany joined the Fund in 1952 with the fifth largest quota. It ascended to the third position in 1959, and the second position in 1992, but reverted to the third position in 1999. Republic of China (Taiwan) lost its seat on the Executive Board

\footnotetext{
${ }^{12}$ The Fund's Articles of Agreement make a distinction between appointed and elected members: under Article XII, Section 3, five Executive Directors shall be 'appointed' by the five members having the largest quotas, with the remaining Directors being 'elected' by the other members.

${ }^{13}$ The Fund's quota increases become effective after members whose quotas represent a specified proportion of the total have consented to them and hence there is uncertainty ex ante about the date when the specified proportion is achieved. The Fund informs members when the threshold is indeed achieved and the quota reforms then become effective. In the case of the fifth review, there was no threshold to be achieved. If the increase in the quotas under the fifth review had become effective too close to the time of the 1970 regular election, the formation of new country groupings for election of Executive Directors might have been challenging for countries losing their 'appointed' status. It was, therefore, considered desirable to give India time to become part of a country grouping that would elect an Executive Director and accordingly, it was agreed that no quota increase under the fifth general review would become effective until after the 1970 regular election. Consequently, while members received their altered voting power on November 1, 1970, the full impact on the line-up of members appointing or electing Executive Directors did not occur until the 1972 regular election (de Vries, 1976).

${ }^{14}$ Republic of China (Taiwan) lost its seat on the Executive Board in 1972, as part of a multi-member constituency, since it did not participate in the regular election of Executive Directors that year, and nor in subsequent elections up to 1980, when recognition of China was finally shifted to the People's Republic of China .
} 
in 1972 and was not represented by any other Executive Director till 1980, when the People's Republic of China was recognized by the Fund. Taking into account the ad hoc quota increase (August 1980) as well as the increase in the seventh general review of quotas (December 1980), the People's Republic of China had the eighth largest quota, exceeded only by the G-7 countries, and had enough votes to elect its own Executive Director (Boughton, 2001).

Despite the existence of the IMF Executive Board, the IC and now the IMFC, there has always been a tendency to discuss key issues related to global governance of economic, financial, economic and monetary issues in smaller groups of major economies. During the 1970s, it was the G-5 (U.S., Germany, Japan, U.K. and France). Canada and Italy joined the G-5 to form the G-7 in 1987 and Russia in 1998 to form the G-8, only to be suspended in 2014. Through the period of their existence, the G-5, G-7 or G-8, many key issues of global economic governance have been deliberated and decided in the formal meetings of their Finance Ministers and Governors, or in summit meetings of leaders. Such decisions are more often legitimized through corresponding Executive Board decisions in matters related to the IMF. In some cases, like the inter-se distribution of quotas among the G-7 countries, the Executive Board has even asked the G-7 to decide among themselves.

Despite the increased and broader membership in the 1990s, as also the increased weight of the EDEs in the global economy beginning in the 1990s, the governance structure of the World Bank and the IMF remains dominated by the AEs, especially skewed towards European countries (Table 7). The 'Advanced Europe' group (European Union, Norway and Switzerland) has a third of the Board Chairs, and more than a third of the voting power on the Board. There is a growing divergence between their shares in the quotas and their weight in the global economy: the relative constancy of their quota shares is striking, even as their share in GDP indicates a consistent downtrend (Chart 10). Even if the 2010 reforms are ratified, there would only be a modest improvement in the governance structure. The skew in favor of the advanced Europe is at the cost of the fast growing EDEs (Table 8), and also the United States.

After the Asian crisis of 1997, and as the weight of large and dynamic EDEs grew, the role of the G-7 began to be supplemented by the G-20 after its formation in 1999. This change in role itself took almost a decade. It was only after the NAFC that the G-20 took a decisive lead role on the global responses to the crisis, rather than the G-7 or G-8. The November, 2008 G-20 Summit meeting held in Washington can perhaps be marked as the decisive turning point of the G-7/8 yielding to the G-20 (Truman, 2008). Among other features of the G-20 role in IMF governance, the 2010 IMF reforms were essentially decided in the 2010 G20 meetings held in Korea; and the Bilateral Agreements to borrow were decided in the 2012 G-20 meetings in Mexico. That these meetings were chaired by non-G$7 / 8$ countries are symbolic of the change taking place in global economic governance. 
Table 7: Executive Board Composition: Number of Chairs

\begin{tabular}{rrrrrr}
\hline & & & & & Advanced \\
Economies & $\begin{array}{r}\text { Advanced } \\
\text { Europe }\end{array}$ & $\begin{array}{r}\text { Other Advanced } \\
\text { Economies }\end{array}$ & $\begin{array}{r}\text { Emerging and } \\
\text { Developing } \\
\text { Economies }\end{array}$ \\
\hline 1946 & 12 & 7 & 5 & 2 & 5 \\
1960 & 18 & 11 & 7 & 4 & 7 \\
1970 & 20 & 11 & 7 & 4 & 9 \\
1980 & 22 & 12 & 8 & 4 & 10 \\
1990 & 22 & 12 & 8 & 4 & 10 \\
1992 & 24 & 13 & 9 & 4 & 11 \\
2000 & 24 & 13 & 9 & 4 & 11 \\
2010 & 24 & 13 & 9 & 4 & 11 \\
2014 & 24 & 12 & 8 & 4 & 12 \\
& $(100.00)$ & $(66.46)$ & $(36.27)$ & $(30.19)$ & $(33.54)$ \\
\hline
\end{tabular}

Note:

Advanced Europe is European Union plus Norway and Switzerland. Includes Spain chair which has since 1978 rotated among Spain, Mexico and Venezuela.

'Other Advanced Economies' comprises the US, Japan, Canada and Australia. The Australian chair has rotated between Australia and Korea since November 2004.

The decline in 'Advanced Europe' in 2014 reflects the move of the chair held by Austria to Turkey in the 2014 elections. Figures in parentheses are percentage vote shares held by these chairs in 2014.

Source: de Vries and Horsefield (1976), de Vries (1976, 1985), Boughton (2001, 2012); and IMF Annual Reports.

\section{Chart 10: European Union: Quotas and GDP (Shares in World Total)}

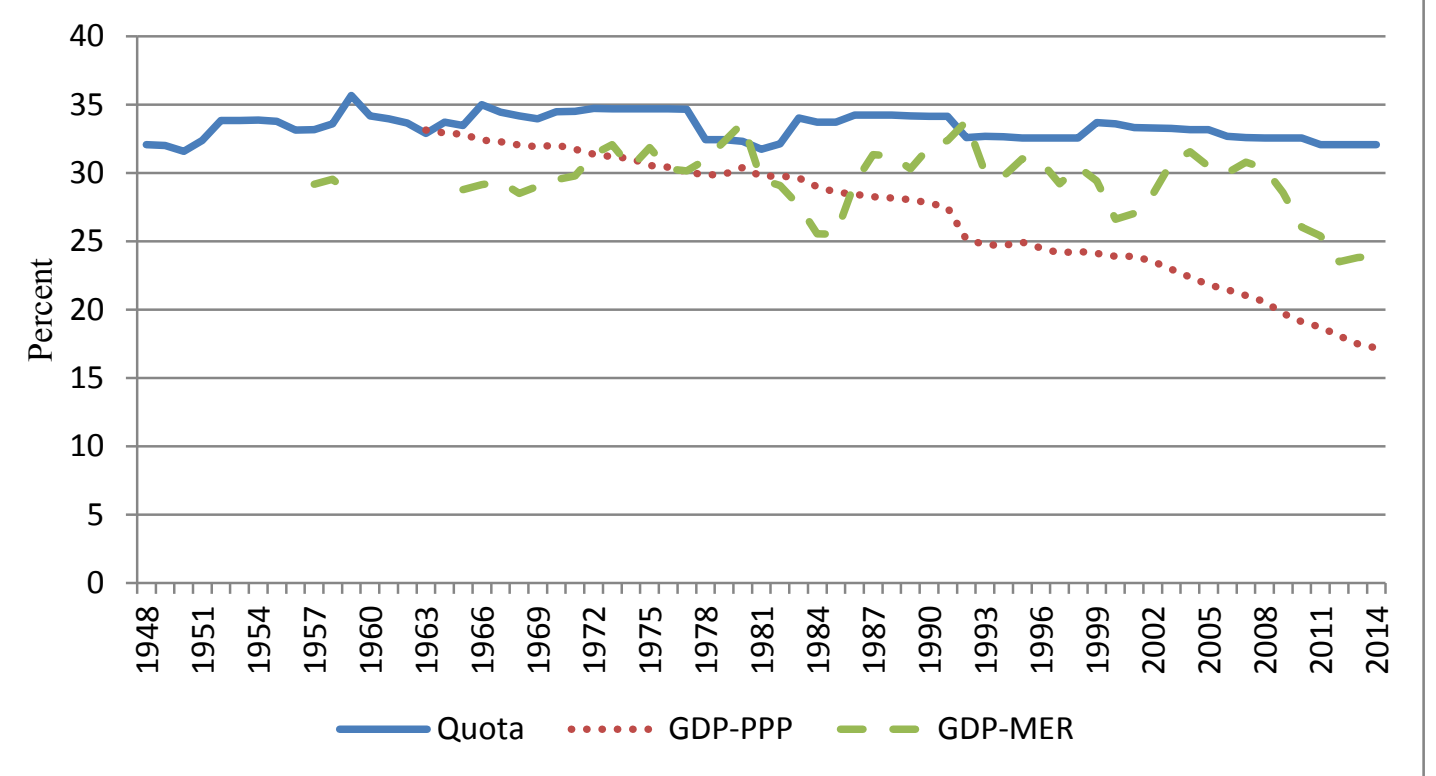

Note: GDP-MER = GDP at market exchange rates; GDP-PPP = GDP at purchasing power parity (PPP) basis.

Source: World Economic Outlook Database (April 2015), IMF; International Financial Statistics, IMF 
Table 8: GDP and Quota Shares: Country-wise

(Percent)

\begin{tabular}{|c|c|c|c|c|c|}
\hline \multirow[b]{2}{*}{ Country } & \multicolumn{2}{|c|}{ Share in GDP-PPP } & \multicolumn{3}{|c|}{ Share in Quota } \\
\hline & 2014 & 2020 & Current (2014) & 14th Review & $\begin{array}{c}\text { CQS, } \\
2012 \\
\end{array}$ \\
\hline China & 16.3 & 18.9 & 4.0 & 6.4 & 10.5 \\
\hline US & 16.1 & 15.0 & 17.7 & 17.4 & 14.9 \\
\hline India & 6.8 & 8.5 & 2.4 & 2.7 & 3.0 \\
\hline Japan & 4.4 & 3.7 & 6.6 & 6.5 & 6.0 \\
\hline Germany & 3.4 & 3.0 & 6.1 & 5.6 & 5.3 \\
\hline Russia & 3.3 & 2.7 & 2.5 & 2.7 & 2.8 \\
\hline Brazil & 3.0 & 2.7 & 1.8 & 2.3 & 2.4 \\
\hline Indonesia & 2.5 & 2.8 & 0.9 & 1.0 & 1.3 \\
\hline France & 2.4 & 2.1 & 4.5 & 4.2 & 3.3 \\
\hline UK & 2.4 & 2.2 & 4.5 & 4.2 & 3.5 \\
\hline Mexico & 2.0 & 2.0 & 1.5 & 1.9 & 1.7 \\
\hline Italy & 2.0 & 1.7 & 3.3 & 3.2 & 2.7 \\
\hline Korea & 1.6 & 1.6 & 1.4 & 1.8 & 1.9 \\
\hline Saudi Arabia & 1.5 & 1.4 & 2.9 & 2.1 & 1.7 \\
\hline Canada & 1.5 & 1.3 & 2.7 & 2.3 & 2.2 \\
\hline Spain & 1.5 & 1.3 & 1.7 & 2.0 & 2.0 \\
\hline Turkey & 1.4 & 1.4 & 0.6 & 1.0 & 1.2 \\
\hline Iran & 1.2 & 1.1 & 0.6 & 0.7 & 0.8 \\
\hline Australia & 1.0 & 1.0 & 1.4 & 1.4 & 1.6 \\
\hline
\end{tabular}

Note:

14th Review $=$ Quota shares agreed according to 2010 reforms (yet to be effective). These were based on data up to 2008 .

CQS, $2012=$ Calculated quota share, based on the 2008 formula, using data up to 2012 .

Source: World Economic Outlook Database (April 2015), IMF; International Financial Statistics, IMF

Furthermore, following on the G20 Washington 2008 Summit where this was first proposed (G20, 2008), it was in the 2009 G-20 Summit meeting held in London, that it was decided to transform the Financial Stability Forum (FSF) into the more formally constituted Financial Stability Board (FSB), thereby opening its membership from the cozy world of leading AEs to wider participation, reflecting that of the G-20. The FSB is now an effective body for arriving at consensual agreements in the sphere of financial regulations and standards in the light of the NAFC.

The growing importance of the EDEs in the global economy since the 1990s is thus now slowly getting somewhat reflected in the current global governance architecture through 
the G20 forum. The G-20's membership is more representative of the global economy. It includes a number of large emerging and developing economies and the member countries have a share of more than 80 percent of global GDP, though the G-20 also has inadequate representation from Africa.

Thus, some significant changes are taking place relative to the previous six decades in the global governance architecture. However, the Bretton Woods institutions seem to be lagging in this process of change. The voting and the voice of these institutions need to reflect appropriately the economic realities so as to effectively address the legitimacy and credibility issues that these institutions are grappling with. The way forward is clear and well-known: a significant realignment of quota shares in the favor of the EDEs.

The Bretton Woods institutions since their inception have been headed by European nationals in the IMF and the US nationals in the World Bank. This pattern has continued for almost seven decades now. It appears that there was an informal agreement that the World Bank would be headed by a US national, and the implicit understanding has been that the IMF would be headed by a non-US national; somehow, over time, this got transformed to a European national heading the IMF on a continuous basis (Boughton, 2001). Thus, nationality per se has turned out to be the guiding criterion to head the Bretton Wood organizations and nationals of other countries, irrespective of their merit, have been excluded from the process.

More change is evident in some other institutions. A welcome exception to this nationality-based principle is the WTO, where three of four Directors-General since 1999 have been non-Europeans - Mike Moore (New Zealand), then Supachai Panitchpakdi (Thailand), 'and now Roberto Azevedo (Brazil). The WTO's predecessor, the GATT, was headed by European nationals throughout its existence. The issue here is not the competence (or the lack of it) of the past heads of the IMF, since most of them have been effective leaders of the institution. Equally effective leaders could come from other members, including the EDEs, an open and transparent choice of the managing director would surely enhance the legitimacy of the Fund and banish the widespread belief that the Fund is run by and for the major industrial countries (Kenen, 2007).

\section{THE WAY FORWARD}

Global economic governance and the IMF are today at a crossroad. The global economy has now become much more complex and inter connected with the expansion of global GDP and other developments that have taken place over the last two or three decades. As international trade has become virtually free across the board as a consequence of the successive rounds under GATT and WTO, and as capital accounts have also become more and more open across the world, there is now much greater financial interconnectedness across borders of countries. Hence, a sneeze in one systemic country can lead to pervasive flu across the globe. A financial crisis in even a non-systemic country could lead to contagion across its region. The large Greece bail-outs in 2010 and 2012 were justified on the basis of a fear of contagion across the Euro zone. Thus, it is clear that in the years and decades to come, the maintenance of financial stability across the world will become more and more difficult and challenging. Attention needs to be given now to the global financial institutional 
architecture that should be in place to help the world manage better and more effectively the fallouts from financial crisis that might occur in the coming decades, despite far reaching ongoing efforts to strengthen financial sector regulation and supervision.

These lessons have become evident as a consequence of the NAFC which resulted in the Great Recession and also the largest ever demand for IMF resources. It is ironic that in the wake of these events the expansion of IMF quota resources and reform has been held up like never before. There are two aspects related to IMF reforms: first, an increase in the size of its quota resources that is commensurate with its role in the global economy for ensuring financial stability and as a lender of last resort, and second, reform in its governance through equitable distribution of voice and vote. Both these reforms are equally important and interconnected. The size of its quota resources should have some relationship to the magnitudes of global GDP, global trade and global financial transactions and the size should be such as to provide credibility in markets in terms of its effectiveness in dealing with potential crises. "The world needs the IMF to function for the benefit of strong and troubled counties alike. Its participation in the stabilization programs for countries in financial crisis in Europe from Ireland to Ukraine was only the most recent example of its indispensable role. But China and other countries have grown vary of the Fund's governance because they see it as failing to recognise their increasing importance in the world economy" (Truman, 2015, p.2).

If the IMF is to be seen as credible, it also needs legitimacy in the eyes of different stakeholders in the global economy. Both the elements of reform are under question today with the stalemate in implementation of the $14^{\text {th }}$ review. The formation of the Asian Infrastructure Investment Bank (AIIB) and the BRICS New Development Bank and the BRICS CRA are all indicators of the EDEs' growing frustration on this account. As noted, IMF quota resources have in fact not been increased in any significant manner since 1998. Because of the stalemate, there is increased dependency on borrowed resources to an extent that is unprecedented in the IMF's history. With the NAB amounting to SDR 370 billion, and the effective commitments through bilateral Borrowing Agreements amounting to SDR 270 billion, the quota resources of SDR 238 billion are now only about 30 percent of the total potential resources available to the IMF. Should the occasion arise to use the significant volume of borrowed resources (actual as well as committed), the IMF would clearly be at greater financial risk relative to a situation where the majority of resources are quota resources. What would happen to IMF's own financial credibility if there is any significant default from large IMF programs? It is also noteworthy that with the NAFC and the European sovereign debt crisis, the size of IMF programs has increased tremendously relative to the size of quotas of the borrowing countries. With and increasingly interconnected financial world, it is not unreasonable to estimate that permanent resources, comprising mostly of quotas, should reach to a magnitude of around US\$ 1.25 trillion by the $17^{\text {th }}$ review (2025), as Truman(2015) has also argued.

The only practical way out of this impasse is indeed for the US to retake leadership in the IMF and global economic governance through an immediate congressional approval of the $14^{\text {th }}$ review. But what is important to understand is that this should be seen only as a beginning of an epochal change in overall global economic governance and in the IMF in particular. The days of cozy arrangements among the G-5/7 or the G-10 that the world was 
used to over the last fifty years of IMF existence are over. With the emergence of more economic powers such as the BRICS countries, the exercise of such leadership will need to find newer institutional mechanisms to share such power across a greater diversity of IMF members.

If the US believes that the IMF is important for the smooth functioning of the global economy, in which it has a large stake, it will make it clear that it is also in favor of discussions and consequent approval of the $15^{\text {th }}$ review, which should in normal circumstances, be approved by end of 2015, and subsequent reviews in the years and decades to come. This is an important issue not from just the US point of view alone. Given the current global economic structure, many others view the role of US leadership in these institutions to be of great value. First, these institutions owe their founding to the far sighted vision of the US leadership post-World War II; second, ironically, even the $14^{\text {th }}$ review would not have been initiated and agreed to without US initiative and leadership. Third, although the emerging economic powers are rapidly seeking higher shares in the global economy and global economic developments, their soft power is not rising commensurately yet, and it will indeed take quite some time along with increases in their per capita income. This "soft power" deficit does not make a case for going slow on re-alignment of quotas in favor of the EDEs, although it increases the importance of US continuing to provide leadership in these institutions as it has done since World War II. In any case, the reallocation in favor of the EDEs, if the existing quota formula is rectified from its analytical weaknesses, would not come at the cost of the US. As noted later, it is the inter se allocation between the US on the one hand and the advanced Europe on the other hand that is of significance. Therefore, an increase in the voice of the EDEs in the IMF's governance structure, despite some deficit with regard to soft power, is consistent with a continued leadership role for the US. Fourth, US financial markets continue to be the most dominant in the world in terms of depth and efficiency. Thus, IMF's effectiveness and credibility is crucially dependent on the kind of confidence that US financial markets place in it. For this, continuous leadership and interest in the governance of the IMF is essential. Finally, the US dollar is still the world's dominant reserve currency and from the current perspective, it will remain as such for the foreseeable future, even as other reserve currencies do rise in importance as expected.

For all these reasons, it is in the interest of global financial stability that the US recognizes its role in global economic governance as it has since the end of World War II.

It is in this context that the $15^{\text {th }}$ and future reviews of IMF quotas and governance need to be more radical in their approach. What is striking is that in addition to the under representation of EDEs, particularly that of the BRICS, as reflected by the gap between their economic weight and quota shares in the IMF, the other country that is most underrepresented in relation to its share in global GDP is indeed the US. Whereas the GDP shares of the US and European Union are broadly comparable, the calculated quota share of the US, based on the latest 2013 data, would be 14.5 per cent, compared to 27.6 per cent of European Union (based on the current quota formula) (Table 9). As Truman (p.6, 2008) argues, "....until the Europeans agree to a substantial reduction of their combined voting share in the IMF from the current European Union share of more than 30 per cent to 
something close to the US share, reducing the US voting share below 15 per cent is a nonstarter.

Table 9: GDP and Quota Shares: Growing Imbalance

\begin{tabular}{|c|c|c|c|c|c|}
\hline & & & & \multicolumn{2}{|c|}{ (per cent to total) } \\
\hline & \multirow{2}{*}{$\begin{array}{l}\text { Current } \\
\text { Quota } \\
\text { Share } \\
(2008)\end{array}$} & \multirow{2}{*}{$\begin{array}{l}\text { Proposed } \\
\text { Quota Share } \\
\text { 14th Review } \\
(2010)\end{array}$} & \multicolumn{3}{|c|}{2013 Data Update } \\
\hline & & & $\begin{array}{c}\text { Calculated } \\
\text { Quota Share }\end{array}$ & $\begin{array}{c}\text { GDP (PPP) } \\
\text { Share }\end{array}$ & $\begin{array}{c}\text { GDP } \\
\text { (MER) } \\
\text { share }\end{array}$ \\
\hline $\mathbf{U S}$ & 17.7 & 17.4 & 14.5 & 16.7 & 22.1 \\
\hline Europe & 32.0 & 30.4 & 27.8 & 17.9 & 23.8 \\
\hline B RICS & 11.5 & 14.7 & 20.0 & 29.5 & 21.0 \\
\hline \multicolumn{6}{|c|}{ 1/ Existing Quota Share, last adjusted in 2008} \\
\hline \multicolumn{6}{|c|}{ 2/ Yet to be implemented } \\
\hline \multicolumn{6}{|c|}{ 3/ Data update based on latest GDP data available for 2013} \\
\hline \multicolumn{6}{|c|}{ 4/ Calculated Quota Share based on formula used for 14th Review } \\
\hline \multicolumn{3}{|c|}{ Source: Tables 1, 2b, IMF (2015) } & & & \\
\hline
\end{tabular}

Very roughly speaking, the current GDP (market exchange rate) shares of the BRICS countries collectively, European Union and the US are broadly similar, whereas the quota shares are quite different. On PPP basis, the GDP share of the BRICS is substantially higher (almost twice) than that of the US and the European Union, The way forward is therefore a significant reform of the quota formula which provides a much greater weight to GDP shares along with whatever other variables that may be considered necessary to be included in the formula.

In order to reduce the very divisive discussion that takes place in every quota review as documented in this paper, consideration should be given to injecting greater automaticity in the size of quota resources that the IMF should have in each review. Consideration could be given to arriving at a formula for deciding on total IMF quota resources on the basis of some desirable proportions of global GDP, total trade merchandise and services and total financial transactions in the global economy ${ }^{15}$. The membership could, for example, agree to maintain some stability in the ratio of overall quotas to world GDP, trade and financial flows so as to avoid the declining trend visible since the 1990s (see Charts 7-8). If such a formula can be arrived at, it would provide great stability to the size of resources, relative to the needs

\footnotetext{
${ }^{15}$ Global output, trade and gross financial flows can be expected to continue with their upward trend and hence the IMF's quota resources need to increase commensurately. Although growth in both AEs and EMDEs has slowed down since the NAFC, its remains substantially positive, with growth in EMDEs still outpacing that in the AEs. Therefore, the view that the level of global output might not increase in the coming decades (there might only be a shift of global output in favour of the EMDEs) and hence there may not be case for an increase in the level of IMF quota resources does not appear to be realistic.
} 
of the global economy, available to the IMF. Such an agreement on the broad principles can helpfully reduce the time spent in the Board's deliberations.

Both the IMF resource and the representation issues are important and need to be addressed simultaneously. As regards the representation issue, the membership should improve the current quota formula by paying heed to the staff's analytical work which has shown that (a) PPP-GDP data of good quality and (b) the 'openness' indicator used in the current formula has serious weaknesses. Such boldness in arriving at consensus for IMF reform cannot take place without significant leadership from IMF management, the G20 and the US as the leading member of the IMF.

It is recognized, of course, that parliamentary/congressional approvals will still be necessary at the time of each quota review and expansion: However, if there is general agreement on the size of IMF resources on a formulaic basis, it can be hoped that there would be less resistance to quota increases since they would no longer be seen as ad hoc responses each time.

We also need to note the emergence of the various regional financial arrangements (RFAs), essentially over the past decade and during the period when IMF quota resources have not significantly increased. The Chiang Mai initiative involving a mutual multilateral swap amongst the ASEAN plus three countries evolved as a consequence of the Asian financial crisis of 1997 and some degree of dissatisfaction with the legitimacy of IMF actions in the resolution of that crisis. This multi currency swap now amounts to a potential total of resources amounting to US\$ 240 billion. The European Stability Mechanism (ESM) has similarly arisen from the European sovereign debt crisis and covers all the Euro zone countries. Its subscribed capital amounts to Euro 700 billion, with paid in capital of Euro 80 billion. The latest entrant to the RFAs is the BRICS currency reserve arrangement (CRA) which is also structured in the nature of a multi currency swap. The potential resources available with the CRA amount to US\$ 100 billion. In addition, there is also a plethora of other bilateral, and some multilateral swap arrangements, that have grown in a manner similar to the increasing number of preferential trade arrangements arising from the failure of the WTO Doha round. Consequently, the total volume of resources available among RFAs and other swap arrangements is in fact greater than the total resources available to the IMF, including its quota and borrowed resources.

Thus, the international financial architecture to deal with global financial stability and resolution of crises is much more dispersed beyond the IMF than was the case until the turn of the century. An ideal solution to avoid an emergence of a plethora of RFAs would be to have IMF's governance structure more attuned to shifting global economic realities. If progress on this front is glacial, as has been the case since the late 1980s, then clearer new arrangements need to be designed on the respective roles of the IMF and these RFAs. In one view, the existing arrangements between the IMF and the RFAs are appropriate and there is no evidence of any coordination failure and hence no need to review the existing architecture. The developments relating to the Greece program involving the troika - the Fund, the European Commission (EC) and the European Central Bank (ECB) - do clearly point towards the need for an improvement in the institutional architecture. As the ex-post evaluation of the Greece program by the IMF's own staff (IMF, 2013) noted: 
There was no "clarity in the assignment of responsibilities across the Troika... Areas of expertise and experience differed within the Troika... The Fund's program experience and ability to move rapidly in formulating policy recommendations were skills that the European institutions lacked... None of the partners seemed to view the arrangement as ideal. There were occasionally marked differences of view within the Troika, particularly with regard to the growth projections. However, the Troika in general seems to have pre-bargained positions so that differences were not on display to the authorities and did not risk slowing the program negotiations. The three institutions also have different internal procedures and the program documentation is voluminous, overlapping, and subject to varying degrees of secrecy. Nonetheless, coordination seems to have been quite good under the circumstances". (IMF, 2013, p.31)

Going forward, the staff review favored exploring "options for dividing up work on areas that are not macro-critical", and "scope for streamlining procedures and documents to reduce the burden on the authorities". (IMF, 2013, p. 34).

It is not apparent if the IMF would have agreed to be a junior partner in arrangements with other RFAs. In the context of the Greece, it may also be relevant to note that the European chairs have a share of as high as 32 percent in the IMF's quotas and thus have a significant voice in the approval of Fund's lending programs. European leaders have also indicated that Europe will be able to handle future economic crises without the help of the IMF (Reuters, 2015). Drawing from the observations of staff evaluation in IMF (2013), there needs to be an improvement in the institutional architecture governing the Fund and the RFAs. Consideration could be given to devising some institutional structure which has representation at the highest levels from the IMF and the various RFAs so that they can play their respective roles in an organized manner in the future. The key to such governance arrangements would need to be perceived legitimacy and voice of the different stakeholders in the global economic system.

The global economy is thus clearly in the cusp of an epochal change and if we have to ensure stability in the global economy and the global financial system, significant changes have to take place so that global economic governance arrangements are seen to be equitable, fair and effective from the point of view of different stakeholders. The era of North American and European dominance is now waning and other economic powers are emerging. This must be recognized and responded to adequately. 


\section{REFERENCES}

Adams, Timothy D. (2005). "The IMF: Back to the Basics", Washington D.C. Institute for International Economics Conference on Reform of the International Monetary Fund . September 23, 2005 available at http://www.treasury.gov/press-center/pressreleases/Pages/hp838.aspx

Benassy-Quere, Agnes and Jean Pisani Ferry (2011), "What International Monetary System for a Fast-Changing World Economy", Brussels: Bruegel Working Paper 2011/06 available at http://bruegel.org/wpcontent/uploads/imported/publications/110404_What_international_monetary system_WP_2 011_06_IMS.pdf

Bolt, J. and J.L. van Zanden (2013), "The First Update of the Maddison Project: ReEstimating Growth Before 1820", Maddison Project Working Paper 4 available at http://www.ggdc.net/maddison/maddison-project/publications/wp4.pdf

Boorman, Jack (2015) "Governance of the Global Economic, Financial, and Monetary System: The G7 and G20, and the Role of the International Monetary Fund," in Kohli, Harinder (ed.) "Prospects for Global Emerging Markets through 2050”. New Delhi: Oxford University Press. Forthcoming."

Boughton, James M. (2001), Silent Revolution: The International Monetary Fund, 19791989, International Monetary Fund, Washington DC available at https://www.imf.org/external/pubs/ft/history/2001/

--- (2012), Tearing Down Walls: The International Monetary Fund, 1990-1999, International Monetary Fund, Washington DC available at https://www.imf.org/external/pubs/ft/history/2012/

de Vries, Margaret G. and J.K. Horsefield (1969), The International Monetary Fund, 19451965: Twenty Years of International Monetary Cooperation, Volume II: Analysis, International Monetary Fund, Washington DC.

de Vries, Margaret G. (1976), The International Monetary Fund, 1966-1971: The System Under Stress, Volume I: Narrative, International Monetary Fund, Washington DC.

de Vries, Margaret G. (1985), The International Monetary Fund, 1972-1978: Cooperation on Trial, Volume I: Narrative and Analysis, International Monetary Fund, Washington DC.

G20 (2008). Declaration: Summit on Financial Markets and the World Economy, Washington DC. November 15, 2008 available at https://g20.org/wpcontent/uploads/2014/12/Washington Declaration 0.pdf

G20 (2015), “Communiqué: G20 Finance Ministers and Central Bank Governors Meeting”, September 4-5, Ankara, Turkey.

International Monetary Fund (1958), "Enlargement of Fund Resources through Increases in Quotas: Report by the Executive Directors to the Board of Governors (December 1958)" in de Vries, Margaret G. and J.K. Horsefield (1969), The International Monetary Fund, 19451965: Twenty Years of International Monetary Cooperation, Volume III: Documents, 
International Monetary Fund, Washington DC.

--- (2000), "Report to the IMF Executive Board of the Quota Formula Review Group", April, available at http://www.imf.org/external/np/tre/quota/2000/eng/qfrg/report/

--- (2002), “Twelfth General Review of Quotas: Alternative Proposal”, December, available at http://www.imf.org/external/np/tre/quota/2002/eng/122002.htm

--- (2003), "IMF Executive Board Recommends to Governors Conclusion of Quota

Review", Press release No. 03/02, January available at http://www.imf.org/external/np/sec/pr/2003/pr0302.htm

--- (2009), Annual Report 2009.

--- (2012), "Quota Formula Review - Initial Considerations", February available at http://www.imf.org/external/np/pp/eng/2012/021012.pdf

---- (2013), Greece: Ex Post Evaluation of Exceptional Access under the 2010 Stand-By

Arrangement, IMF Country Report No. 13/156, June

--- (2014a), "Quota Formula - Data Update and Further Considerations", August available at http://www.imf.org/external/np/pp/eng/2014/070214.pdf

--- (2014b), "Quota Formula - Data Update and Further Considerations - Annexes", August available at http://www.imf.org/external/np/pp/eng/2014/070214a.pdf

--- (2014c), "Quota Formula - Data Update and Further Considerations - Statistical Appendix", August available at http://www.imf.org/external/np/pp/eng/2014/070214b.pdf

-- $\quad$ (2014d), IMF Financial Operations available at http://www.imf.org/external/pubs/ft/finop/2014/

--- (2015a), World Economic Outlook Database, April available at http://www.imf.org/external/pubs/ft/weo/2015/01/weodata/index.aspx

--- (2015b), "Quota Formula - Data Update", July available at http://www.imf.org/external/np/pp/eng/2015/061915.pdf

Kenen, Peter (2007), "Reform of the International Monetary Fund", CSR No. 29, Council on Foreign Relations, Washington DC, May available at http://www.cfr.org/internationalorganizations-and-alliances/reform-international-monetary-fund/p13276

Lagarde, Christine (2015), "Lagarde Urges More Global Action to Support Growth and Jobs", Press Release 15/403, International Monetary Fund, September 5.

Lew, Jack (2015), "Testimony of Secretary Lew before the House Financial Services Committee on the National Advisory Council on International Monetary and Financial Policies", March 17, available at: http://www.treasury.gov/press-center/pressreleases/Pages/j19999.aspx

Mikesell, Raymond (1994), "The Bretton Woods Debates: A Memoir", Essays in International Finance, No. 192, Princeton University, Princeton, New Jersey available at http://www.princeton.edu/ ies/IES_Essays/E192.pdf 
Mirakhor, Abbas and Iqbal Zaidi (2006), "Rethinking the Governance of the International Monetary Fund", Working Paper WP/06/273, International Monetary Fund, Washington DC available at http://www.imf.org/external/pubs/ft/wp/2006/wp06273.pdf

Mountford, Alexander (2008). "The Historical Development of IMF Governance". Independent Evaluation Office Background Paper, Washington D.C., International Monetary Fund available at http://www.imf.org/ieo/files/completedevaluations/05212008BP08_02.pdf

Organization for Economic Cooperation and Development (OECD) (2014), Economic Outlook 95 - Long-term Baseline Projections Dataset, May available at https://stats.oecd.org/Index.aspx?DataSetCode=EO95 LTB

Pritchett, Lant and Lawrence Summers (2014), “Asiphoria Meets Regression to the Mean”, in Reuven Glick and Mark Spiegel (ed.), Prospects for Asia and the Global Economy, Asia Policy Conference, Federal Reserve Bank of San Francisco, pp. 33-91 available at http://www.frbsf.org/economic-research/events/2013/november/asia-economic-policyconference/Pritchett-Summers-AEPC2013.pdf

Reuters (2015), "Europe can Handle Future Crises without IMF - Bailout Fund Chief", August 28.

Snow, John W. (2005). Statement by the Honorable John W. Snow U.S. Secretary of the Treasury On behalf of the United States of America. Washington DC. International Monetary Fund : International Monetary and Financial Committee Eleventh Meeting April 16, 2005 available at https://www.imf.org/External/spring/2005/imfc/stmt/eng/usa.pdf

Truman, Edwin (2008), “On What Terms is the IMF Worth Funding?”, Working Paper 0811, Peterson Institute for International Economics, Washington DC available at http://piie.com/publications/interstitial.cfm?ResearchID $=1075$

--- (2015), “What Next for the IMF?” Policy Brief 15-1, Peterson Institute for International Economics, Washington DC available at http://piie.com/publications/interstitial.cfm?ResearchID $=2742$

Virmani, Arvind (2011), “Global Economic Governance: IMF Quota Reform”, Working Paper WP/11/208, International Monetary Fund, Washington DC available at http://www.imf.org/external/pubs/ft/wp/2011/wp11208.pdf

Virmani, Arvind and Michael Patra (2011), "IMF Reforms 2010: Do They Mirror Global Economic Realities?", Economic and Political Weekly, Vol. XLVI, No. 30, pp. 53-61 available at http://www.epw.in/special-articles/imf-reforms-2010-do-they-mirror-globaleconomic-realities.html 